\title{
RAND
}

\section{Disability from Injuries at Work: The Effects on Earnings and Employment}

\author{
Robert T. Reville \\ Robert F. Schoeni
}

DRU-2554

May 2001

\section{Labor and Population Program}

\section{Working Paper Series 01-08}

The RAND unrestricted draft series is intended to transmit preliminary results of RAND research. Unrestricted drafts have not been formally reviewed or edited. The views and conclusions expressed are tentative. A draft should not be cited or quoted without permission of the author, unless the preface grants such permission. 


\title{
DISABILITY FROM INJURIES AT WORK: THE EFFECTS ON EARNINGS AND EMPLOYMENT
}

\author{
Robert T. Reville \\ Robert F. Schoeni \\ RAND \\ 1700 Main Street \\ Santa Monica, CA 90407
}

May 2001

This research was funded by the Commission on Health and Safety and Workers Compensation for the State of California, and we thank them for their support. We thank Jeremy Arkes, Brigitte Madrian, Steve Haider, Arie Kapteyn, Darius Lakdawalla, Craig Martin, Dan McCaffrey, Frank Neuhauser, Chad Shirley and seminar participants at Case Western Reserve University, the University of Michigan, Society of Labor Economics, and the 2000 Workers' Compensation Research Group for comments. We thank Craig Martin for data analysis. 


\title{
DISABILITY FROM INJURIES AT WORK: THE EFFECTS ON EARNINGS AND EMPLOYMENT
}

\begin{abstract}
This study estimates the earnings losses associated with workplace injuries that lead to permanent partial disability. Using unique administrative data from California, injured workers are matched to their co-workers with similar pre-injury earnings. Earnings loss is estimated as the difference in earnings between these two groups following injury. It is found that earnings losses are large. Moreover, despite the fact that earnings rebound after an initial steep fall, four to five years after injury earnings losses are 25 percent. A large share of the earnings loss is due to lower employment after injury among injured workers. Earnings losses are smaller for workers: with less severe injuries, lower pre-injury earnings, employed in larger firms, and injured when the labor market is robust. Workers suffering from spinal cord injuries and psychiatric disorders experienced particularly large losses. Workers employed in manufacturing industries experience the largest losses; however, the disparities across industries are an artifact of differential severity of injuries and pre-injury earnings. There is some evidence that suggests that benefits are not equitable: some workers receiving different disability ratings and benefits experience the same loss in earnings. Finally, there is no evidence that the 21 percent increase in temporary total disability benefits in California in 1994 affected employment or earnings losses in the long run.
\end{abstract}




\section{THE EFFECTS OF WORKPLACE INJURIES ON EARNINGS AND EMPLOYMENT: THE CASE OF PERMANENT PARTIAL DISABILITY}

\section{INTRODUCTION}

There were an estimated 5.7 million injuries and illnesses reported in the private industry workplace in 1999, for a rate of 6.3 per 100 equivalent full-time workers. These cases range from cuts and scrapes to carpal tunnel to amputation to mental illness. In many cases, the injuries and illnesses result in chronic health conditions that may affect earnings and employment for years after injury. These more serious injuries are referred to as permanent partial disability and are a significant pathway into the disabled population, accounting for as many as one-quarter to one-third of the disabled population (Reville et al, 2001). In this study, we examine the long-term labor market consequences of permanent partial disabilities.

The workers' compensation system is designed to compensate injuries and illnesses acquired at work. For the most part, workers' compensation is a state system with mandatory participation.

Employees receive medical treatment and cash benefits when they are injured at work without having to prove the employer is at fault. Employers pay premiums to support benefits in exchange for limited liability. In general, firms with more injuries and illnesses pay higher premiums; that is, the firms are experience rated.

The workers' compensation system is costly. In 1993, which is the middle of the period analyzed in this study, workers' compensation costs accounted for 2.1 percent of employee compensation nationally. To put this in perspective, the cost of Unemployment Insurance (UI) was roughly one-third as high, at 0.6 percent of employee compensation. Social Security taxes and health insurance benefits were 5.6 percent and 6.8 percent, respectively (DOL, 2000). In California, which is the focus of this study, benefits (medical and indemnity) paid to claims for permanent partial disability alone cost roughly $\$ 5.0$ billion per year. Again, to place this cost in perspective, UI benefits totaled \$2.6 billion in California in 1999 (DOL, 2001); state and federal welfare expenditures in the form of Temporary Assistance to Needy Families were $\$ 6.3$ billion (DHHS, 2000).

Injured workers receive three primary forms of assistance: indemnity benefits, medical benefits, and vocational rehabilitation benefits. Indemnity benefits take one of four forms. A worker who is temporarily able to work only part time or at a reduced wage will receive Temporary Partial Disability benefits. At the other extreme, a worker whose injury permanently renders them incapable of working will receive Permanent Total Disability benefits. Relatively few claimants receive either of these two types of benefits. More common are Temporary Total Disability (TTD) benefits and Permanent Partial 
Disability (PPD) benefits. As the name suggests, TTD benefits are paid to workers who are temporarily unable to work while recovering from an injury. Once a worker has obtained maximum medical recovery or they return to work, and if the injury has led to a permanent impairment of their ability to work, they are eligible to receive PPD benefits. Specifically, PPD benefits compensate workers with permanent impairments for their "loss of ability to compete in the open labor market." In California, roughly 40 percent of all indemnity claims include PPD, and 65 percent of indemnity costs are PPD benefits. Aside from the one to two percent of cases that receive permanent total disability, PPD cases are the most serious injuries, with the most lasting effects.

The objective of this study is to estimate the employment and earnings losses associated with workplace injuries, with a focus on injuries with the most lasting economic consequences, those that lead to PPD benefits. Alternatively, this study can be seen as an analysis of the labor market consequences of disability on a population of workers observed before and after disability onset. Using administrative data from California, injured workers are matched with their uninjured co-workers at the same firm who had similar wages prior to injury. The estimate of earnings loss is the difference in earnings of injured workers and their co-workers before injury, minus the difference after injury, where by design there is no difference in earnings between the injured workers and their co-workers prior to injury. This approach is then extended to examine a variety of issues, including the effects of legislated increases in TTD benefits on employment and earnings, the importance of local labor market conditions, disparities across industries, the role of firm size, and the validity of the disability rating system.

The size of the sample and the methodological approach in this study permit a more comprehensive analysis of the long-term earnings and employment consequences of permanently disabling injuries than has been possible in other studies of the earnings consequences of workplace injuries, such as Boden and Galizzi (1999a, 1999b), Biddle (1998), Johnson, Cullinan, and Curington (1978), and Berkowitz and Burton (1987). With increased policy and academic interest in employment among the disabled population during the 1990s, this paper also provides new insight into a common pathway into disability.

The paper begins by describing the mechanisms through which workplace injuries affect earnings and employment. Section III describes the estimator of earnings loss, which is based on matching. Subsequent sections describe the data and results. The final section summarizes and discusses the implications of the findings.

\section{CONCEPTUAL FRAMEWORK}

Workplace injuries can lead to reductions in wages and hours for a variety of reasons. If the injured 
worker spends time out of the labor market receiving treatment or recuperating, then she forfeits her earnings during her recovery as well as the accumulation of human capital that she would have otherwise experienced. In addition, the injury may cause a loss in health human capital. The nature and severity of the injury combined with the physical and mental requirements of the job determine the extent to which the injury affects the worker's productivity. Moreover, the injured worker may lose job-, firm-, or industry-specific human capital. The worker may be required to switch firms because the firm at which she was injured did not have employment opportunities that fit the injured worker's new, more limited abilities. In this case the worker loses firm-specific and perhaps industry-specific human capital. Moreover, if the job paid a premium because of the presence of unions or efficiency wages, changing jobs, firms, or industries may result in the loss of this premium. Furthermore, even if the worker could remain on the same job with the same firm, her productivity may diminish. For example, a worker with carpal tunnel may be able to continue to work at a computer, but her proficiency may be severely reduced.

The labor market consequences of the injury can be mitigated by various factors. Some firms have more aggressive policies to assist injured workers return to work. In addition, larger firms, which simply have a greater number of occupations, may be more able to find a new job that accommodates the worker's more limited abilities. Furthermore, larger firms are more likely to be experience-rated, providing an incentive to help injured workers return to work more quickly. Local labor market conditions may also play a role. If a worker is injured when the labor market is robust, firms may be more willing to accommodate workers, perhaps reducing wage losses.

Compensating differentials may also affect the observed loss in earnings. If the wage of a particular job partially reflects the probability of injury and the amount of wage losses conditional on injury, then for workers who switch jobs following injury, the reduction in earnings following injury may simply represent the loss of the premium that the worker received for holding a particularly risky job.

Our focus in this study is on the extent of earnings losses from permanent partial disability and its determinants, and not on the adequacy and equity of workers' compensation benefits. However, the earnings losses associated with workplace injuries are only partially compensated by the workers' compensation system (Reville (1999), Reville et al, 2000; Boden and Galizzi (1999a, 1999b), Biddle (1998), Johnson, Cullinan, and Curington (1978), and Berkowitz and Burton (1987). The extent to which these losses are replaced depends upon the level of benefits in the state as well as, within state, on the type of injury.

At the same time, by the incentives and disincentives to employment that it provides, the workers' compensation benefit system itself affects earnings losses. PPD benefits are paid to workers whose injuries are permanent but who are expected to be able to return to work. PPD benefits are not a function 
of the actual post-injury earnings or employment of the injured worker (in most states) and therefore would not be expected to lead to a substitution effect, but PPD benefits may induce an income effect on leisure, causing time-out-of-work to increase. For most workers with permanent partial injuries, there is a period immediately following injury during which they receive TTD payments. Because workers stop receiving TTD benefits when they have returned to work, TTD benefits induce a substitution effect, making it more attractive to remain out of the labor force. At the same time, if the injured worker is liquidity constrained, TTD (and PPD) payments will allow injured workers to remain out of work long enough to either receive effective treatment or find employment that best fits their new, more limited health condition. If TTD payments simply generate an income effect on leisure (and the time out of work arising from purchasing leisure does not reduce human capital), then we would expect that workers with higher TTD payments would have a larger reduction in employment (and quarterly earnings), but in the longer run they would have outcomes no different from workers with lower TTD payments. But if TTD payments allow workers to find better matches and spend time out of work addressing their health conditions, then enhanced TTD benefits may lead to better long run employment and earnings. These issues will be explored by analyzing the legislative change in TTD payments that occurred for some groups of workers in 1994.

\section{DEFINING AND ESTIMATING EARNINGS LOSS}

In Figure 1, the earnings of a hypothetical worker who experiences a workplace injury and then returns to regular employment are plotted over time together with the earnings the worker would have received had she not been injured. We will refer to the actual earnings experience of injured workers as observed injured earnings and the counterfactual earnings as latent uninjured earnings. Observed injured earnings are represented in Figure 1 by the dark solid line, and we will denote it by $y_{q}^{I}$ where $I$ denotes "injured" and the subscript $q$ denotes quarters from the injury. Latent uninjured earnings is represented by the dashed line and is denoted by $y_{q}^{U}$. Symbolically, for any individual, the earnings loss in quarter $q$ is:

$$
\text { Earnings Loss }=y_{q}^{U}-y_{q}^{I}
$$

After the injury, $y_{q}^{I}$ is zero until the worker returns to work. This is the period during which the worker would receive temporary total disability payments. After returning to work, earnings increase and eventually exceed the pre-injury earnings. However, in this example the worker continues to experience earnings loss throughout the entire period of observation. While $y_{q}^{I}$ increases, $y_{q}^{U}$ also increases, representing accumulated experience in the labor force and tenure at the firm. Even when the earnings of 
an injured worker returns to its pre-injury level, the worker may be suffering substantial losses because their earnings had they not been injured, $y^{U}$, would have risen.

If we could observe both the injured and uninjured earnings in Figure 1 for every injured worker, estimating earnings loss would be straightforward and given by equation (1) above. However, $y_{q}^{U}$ cannot be observed, and an estimate, $\hat{y}_{q}^{U}$, must be constructed. As already noted, pre-injury earnings would not be a suitable choice as an estimator for $y_{q}^{U}$ because the worker most likely would have experienced gains in earnings associated with tenure and experience.

Our approach to estimating the latent uninjured earnings is to compare the earnings of permanent partial disability (PPD) claimants to a comparison or control group of non-claimants. This approach draws its inspiration from the training program evaluation literature and the matching literature more generally (Dehejia and Wahba, 1996; Heckman and Hotz, 1989; Heckman, Ichimura and Todd, 1997; Holland, 1986; Lalonde, 1986; Rubin, 1973, 1979). If PPD claims were randomly assigned to workers, a control group would be a random sample of workers in California. However, for several reasons, PPD claims are not randomly assigned. First, some industries are more likely to have injuries than others. Second, within an industry, there are differences among firms in injuries and in claiming. For instance, unionized firms have more claims than nonunionized firms (Hirsch, MacPherson, and Dumond, 1997). In addition, some firms may have in place procedures that minimize injuries or claims, such as safety awards for supervisors. Third, within a firm, there are differences among employees in the probability of an accident and in the probability of making a PPD claim given that an accident occurs.

For these reasons, we match each PPD claimant as closely as possible to workers with similar characteristics. Our data, which contain earnings for roughly 95 percent of workers employed in California, make it possible to link within firm to workers with similar earnings at the time the injured worker was injured. We match every injured worker with up to 10 controls who are working in the same firm, and therefore also in the same industry, in which the injured worker worked in the quarter of injury. These matching criteria ensure that the firm and industry conditions are held constant, and that the local economic conditions facing the control and the injured worker are also the same. Within the firm, we require that the control have earnings that are similar to the earnings received by the injured worker prior to injury.

Formally, let us define the weighting function $w\left(y_{j \tau}, x_{j \tau}, z_{j}\right), \tau=\ldots,-1,0,1,2, \ldots T$, where $j$ indexes all potential controls (all workers in California), $y_{j \tau}$ denotes the earnings history of control $j, x_{j \tau}$ 
denotes the firm history of control $j$, and $z_{j}$ denotes a set of control $j$ 's other characteristics. For every injured worker we estimate the latent uninjured earnings in period $q$ by

$$
\hat{y}_{q}^{U}=\frac{1}{\sum_{j} w\left(y_{j \tau}, x_{j \tau}, z_{j}\right)} \sum_{j} w\left(y_{j \tau}, y_{j \tau}, z_{j}\right) y_{j q}
$$

The weighting function is defined simply in this paper. Let $q=0$ denote the period of injury. If $y_{j(-1)}=y_{i(-1)}$ and $x_{j 0}=x_{i 0}$, then $w\left(y_{j \tau}, x_{j \tau}, z_{j}\right)=1$. Otherwise $w\left(y_{j \tau}, x_{j \tau}, z_{j}\right)=0$. In other words, if the earnings of the control are similar to the earnings of the injured worker just prior to injury, and if the injured worker and the control work at the same firm at the time of injury, then the control's earnings are used for the calculation of the latent uninjured earnings in subsequent periods.

More specifically, we require that the control worker have earnings in the injured worker's firm in the quarter of injury and have worked in at least one of the four quarters prior to the injury. In addition, we require that the control have average quarterly earnings within a band around the earnings of the injured worker. That is, we average the earnings for the injured worker in the four quarters prior to injury to obtain an average quarterly earnings. Once a potential control worker is found working at the same firm, that individual can be a control for the injured worker only if the log of the average quarterly earnings of the potential control worker is equal to the injured worker's log average quarterly earnings plus or minus 10 percent of the standard deviation of the log average quarterly earnings of the population of PPD claimants for injuries in that quarter.

For example, for a worker with average quarterly earnings of $\$ 3,000$, the log average quarterly earnings is 8.01. If the injury occurred in first quarter 1993, the standard deviation of the log average quarterly earnings is 0.80 . Therefore, the log of the average quarterly earnings of the control must be between 7.93 and 8.09. This implies a range in dollars between $\$ 2,779$ and $\$ 3,262$. The average for the control is taken over the five quarters prior to and including the injured worker's quarter of injury. For both the injured workers and the controls, if earnings are not found in a quarter prior to the injury quarter, the missing quarter is not included in the average. We selected up to 10 controls per worker. The latent uninjured earnings, $\hat{y}_{q}^{U}$, is an average using the $n$ controls for each injured worker, and each control is weighted by $1 / n$.

It is possible that among workers within the same firm making the same earnings, workers who make PPD claims will be systematically different from those who do not. Since the data from which the controls are drawn do not contain demographic variables that can be used in the matching, there may be 
differences in gender, tenure, age, education, and other characteristics between the injured workers and their controls. However, to the degree that these characteristics do not affect the probability of injuries or PPD claims after conditioning on industry, firm, and earnings, the sample of controls should have the same characteristics as the sample of injured workers. Below we show evidence that this is the case. In particular, we find that earnings of the injured and control workers are nearly identical even four to five years prior to injury. ${ }^{1}$

Various approaches to the estimation of earnings loss for injured workers have been used in the literature. While the primary statistical problem that these studies faced is the same, namely, accurately estimating $y^{U}$, our methodology and data differ. Boden and Galizzi (1999a, 1999b), Biddle (1998), Johnson, Cullinan, and Curington (1978), and Berkowitz and Burton (1987) used a regression approach with workers suffering minor injuries as the control group. The regression corrects for observable differences between the controls and injured workers. But workers with the least severe injuries may still be effected by their injury, confounding any comparison. Furthermore, the regression approach places greater parametric assumptions on the data than does our matching approach. Krueger and Kruse's (1995) study of the labor market consequences of spinal cord injuries is most similar to ours. They ask victims of spinal cord injuries for the names of (pre-injury) co-workers who were similar to themselves. They then attempted to contact these co-workers to obtain labor market outcomes. Using survey and administrative data, they then compare the earnings of the injured worker with their co-worker. This study has a clear focus on one type of important injury. Our study will also estimate earnings losses associated with a few important specific injuries - spinal cord, lower back, psychiatric or mental stress, and carpal tunnel - but the focus will be on the broader set of permanent and partial workplace injuries.

There are several parallels between our approach and the approach used by Jacobson, LaLonde, and Sullivan (1993), who examine the effects of job displacement on earnings in Pennsylvania . Like our study, they use base wage administrative data and estimate earnings losses as the gap between the earnings of the displaced worker and non-displaced co-workers. One difference of our study is that we additionally match on co-workers with similar pre-injury earnings using a nonparametric case-control method.

\footnotetext{
${ }^{1}$ More complicated matching could be designed. For example, matching could have been made on the level of earnings and the growth in earnings during several years prior to injury. However, we were limited by the fact that all matching was conducted by employees of the State of California; we did not have direct access to the entire base wage database. Therefore, the goal was to choose a matching algorithm that was simple enough for the state employees to program but yet complicated enough to obtain an accurate estimate of earnings loss.
} 
Finally, the estimate of actual earnings loss should not be interpreted as an estimate of earnings capacity. Some injured workers who are out of the labor force could clearly return to work at some wage level, even if it is much lower than they are accustomed to. On the other hand, time spent out of work is an important cause of earnings losses. As a result, we estimate employment losses using the same method that we use for estimating earnings losses.

\section{ECONOMETRIC MODELS}

Earnings loss can be estimated quite easily using equation (1). That is, earnings loss is defined as the difference in the average earnings of injured workers and the average earnings of control workers, where controls' earnings are weighted by the inverse of the number of controls for the given injured worker. This approach has been implemented by Reville (1999) using a limited set of the data available to us here.

However, when estimating differences across groups - e.g., workers at big firms and small firms, severely injured workers and less severely injured workers - we want to adjust for other observable factors, and our samples are not large enough to disaggregate all of our estimates across all factors. For example, although we can precisely estimate earnings loss for workers in firms of different sizes, we cannot precisely estimate earnings loss for workers with the least severe injuries in smaller firms who were injured during robust economic conditions and had relatively low pre-injury earnings. Moreover, disaggregating the estimates along all of these dimensions simultaneously would provide an overwhelming number of estimates that would be difficult to interpret.

Therefore, a regression framework is used where confounding factors are adjusted. In addition, we choose a parsimonious specification because we are interested in examining how the path of earnings losses varies across several groups. Consider first the basic model that describes earnings losses for injured worker $i$ in quarter $q$ :

$$
\bar{y}_{i q}^{U}-y_{i q}^{I}=\sum_{k=-20}^{-1} \beta_{k} D_{i q}^{k}+\beta_{d i p} D I P_{i q}+\beta_{d r o p} D R O P_{i q}+\beta_{\text {re covery }} R E C O V E R Y_{i q}+\varepsilon_{i q}
$$

where the dependent variable is the difference between the earnings of the injured worker and the average earnings of their matches, as defined in equation (1), in quarter $q$. Observations for which the dependent variable is zero are included in the analytical sample. The parameters within the summation, $\beta_{k}$, represent the difference between injured workers and their controls in each quarter prior to injury, similar to Jacobson, LaLonde and Sullivan (1993). That is, each variable within the summation is an indicator that takes the value of one if the observation is $q$ quarters prior to injury. By design, the gap between injured workers and their co-workers is (close to) zero in the four quarters prior to injury, and as we will 
demonstrate below, the earnings of these two groups are virtually identical during the entire preceding four to five years.

In choosing the specification of the path of earnings loss, there exists a tradeoff between parsimony on the one hand and accurate representation of the profile of earnings losses on the other. However, after exploring several alternative models, a three-parameter specification - "dip," "drop," and "recovery" - was found to represent the data quite well across the various groups. DIP takes the value of one during the quarter of injury, and zero otherwise. On average, half of the quarter of injury is spent with the injury, so in some sense $\beta_{\text {dip }}$ represents the transition period to disability. DROP equals the value of one in the quarter after injury and all subsequent quarters (i.e., $q>0$ ), and 0 in all other quarters.

RECOVERY takes the value of zero in all quarters prior to the second quarter after injury, it then takes the value one in the second quarter after injury, the value two in the third quarter after injury, the value three in the fourth quarter after injury and so on. This specification is similar to the one used by Krueger and Kruse (1995) except that their "drop" is the difference in earnings three quarters instead of one quarter after injury, and recovery is the annual improvement beginning one year after injury.

To evaluate the accuracy of the parsimonious specification, Figure 2 displays the simple difference in earnings between injured workers and their controls (equation 1), as well as the earnings loss implied by estimates of "dip," "drop," and "recovery" in model (3). The two paths are almost identical, lending support for the specification in equation (3).

Equation (3) is then expanded to allow the path of earnings loss to vary across subgroups by interacting each factor with the "dip," "drop," and "recovery" variables. Six factors will be considered: severity of injury, pre-injury earnings, firm size, year of injury, TTD policy change, local (county) economic conditions, and industry of employment at the time of injury. ${ }^{2}$ Models are presented in which each factor is interacted individually, as well as a fuller model in which all factors are simultaneously interacted with "dip," "drop," and "recovery."

A substantial component of earnings loss is time out of work. While our data do not permit us to examine hours or weeks worked within a quarter, we do examine whether the worker had any earnings at all. Therefore, a set of models analogous to (3) are estimated where the dependent variable is the employment of the injured worker minus the average of the employment status of the injured worker's controls. As a result, this outcome ranges from -1 to +1 . We suppress the estimates of "dip" in the tables that report the employment models because, due to the matching design, they are very close to zero in all 
cases. Finally, all estimates of the standard errors account for general forms of heterscedasticity using the Huber-White method, with clustering within individuals over time.

\section{DATA}

An unusually rich database was constructed by linking data files from two California state agencies.

Workers' compensation claims data are linked to earnings data for the claimant based on their Social

Security Number, and this information is combined with earnings data to identify the control group. In this section, the data and its limitations are described. An appendix is provided with additional information on the construction of the linked administrative databases and on the use of the claims data to construct benefit streams.

Claims data from the Workers' Compensation Insurance Ratings Bureau (WCIRB) are linked to earnings data from the State of California Employment Development Department (EDD). The claims data are from the Uniform Statistical Reporting Plan (USR) database from the WCIRB, a private entity responsible for advising insurers on workers' compensation insurance premiums. All claims for permanent partial disability in insured firms in California are reported to the WCIRB. We received data for claims that occurred on policies that opened from 1989 to $1995 .{ }^{3}$ The data from the WCIRB provide detailed information about the characteristics of claims and injuries, benefits and expenses as they were incurred and paid, and some information about how claims were processed. These data are provided only for claims submitted against employers who are covered by workers' compensation insurance carriers, which account for approximately 70 percent of the PPD claims within California. There is no comparable database on claims filed against self-insured employers in California. ${ }^{4}$

The earnings data are from the Base Wage file maintained by EDD. Every quarter, employers covered by Unemployment Insurance (UI) in California are required to report the quarterly earnings of every employee to the EDD. These reports are stored in the Base Wage file. The industries covered by UI are virtually identical to the industries covered by workers' compensation ${ }^{5}$ and therefore a worker injured at a firm for which he or she can make a workers' compensation claim should also have a record for that quarter in the Base Wage file. With roughly 95 percent of employees in California covered by the UI

\footnotetext{
${ }^{2}$ Two variables were included in the model to adjust for the maturity of the claim data that were available. This issue is discussed in more detail in the appendix. All of these factors are interacted with dip, drop, and recovery.

${ }^{3}$ Policies reopen every year, and therefore all policies with claims are included.

${ }^{4}$ Reville, Seabury, Polich, and Giddens (2000) collect data from a sample of self-insured employers in California and do not find qualitatively different earnings consequences for workers at these firms.

${ }^{5}$ In both systems, federal civilian and military employees, U.S. postal service workers, railroad employees, and the self-employed are excluded.
} 
system, the matched WCIRB-EDD data provide a substantially complete and accurate California quarterly earnings history for PPD claimants. Claims data from injuries occurring in 1991-1995 were linked to earnings data for every claimant from the first quarter of 1990 through the fourth quarter of 1998. All dollar values are expressed in 1997 values using the CPI-U. ${ }^{6}$

The match rate between the WCIRB and the EDD data was very high, with over 90 percent of injured workers in the WCIRB files matched to usable earnings data in the EDD files. A 20 percent random sample was drawn from this matched sample, and then the controls were selected. Two-thirds of this sample was matched to at least one control, and unmatched claims were dropped from the analysis. The primary reason for not finding a match was that workers in small firms were less likely to have a coworker with earnings in the allowed wage band. ${ }^{7}$ This factor will lead to a sample that over represents workers at larger firms. ${ }^{8}$ Table A1 compares the characteristics of the injured workers who could and could not be matched to controls. The median firm size is almost twice as high for injured workers who could be matched with a comparably paid co-worker. At the same time, there are some workers who are at very large firms who could not be matched to co-workers, causing the average firm size and the $75^{\text {th }}$ percentile to be higher for the controls. The samples are also different in that matched workers have 9 percent higher average weekly wages prior to injury, a result that is not surprising because workers in larger firms have higher earnings (Brown and Medoff, 1989). Although the samples are different on these two dimensions, they are very similar in terms of industry of employment and severity of injury, which is the most powerful predictor of earnings loss.

To examine the ramifications of these differences, the estimated model in the right panel of Table 2 (described below) is used to simulate the earnings losses for unmatched workers based on their observable characteristics (i.e., severity of injury, pre-injury earnings, firm size, local economic conditions, industry of employment, and year of injury). Earnings losses for the total sample - matched and unmatched workers - are 2 to 3 percent higher than the estimate of earnings losses for the matched sample alone (Table A2), implying that the inability to obtain matches for all injured workers had very little effect on the estimates.

\footnotetext{
${ }^{6} \mathrm{We}$ do not restrict our analysis to closed claims. Closed claims may be an unrepresentative sample of claims.

${ }^{7}$ However, a miscommunication between EDD and the authors contributed to the reduced match rate. In particular, the wage band for the injured worker is based on wages at all firms, but the controls were initially chosen by EDD using the wages at only the firm of injury. This led to controls with wages that were higher on average than wages of the injured workers. Since a second extraction of controls was not feasible, we selected the controls using wages at all firms from among the controls received from EDD.
} 
The EDD data has limitations. First, the data do not report earnings in the uncovered sector, or more importantly, earnings in another state. The control methodology is partly intended to correct for this problem. Only if the injured worker is more likely than the control to receive earnings in the uncovered sector or out of state will this bias the result. To investigate this issue we examined cross-state migration among workers who did and did not report receiving workers' compensation. Using data from the 19911998 March CPS (the period covered by our California data), we find that the percent of working age respondents (ages 25-55) who had moved across state lines in the 12 months prior to the survey was virtually identical for respondents who did and did not report receiving workers' compensation (Figure 3). This evidence suggests that any bias arising from differential migration out of California is likely to be small.

Another limitation of the EDD data is the level of earnings reported, which is quarterly. With quarterly earnings, if two workers make the same weekly wage and one works only half of the quarter, the latter worker will have lower quarterly earnings. Moreover, demographic information is not available, which limits our ability to examine differences among claimants.

The data file does include the location (i.e., county) of the firm at which the injured worker was employed. This information is used to link county-level labor market indicators - unemployment rate and employment growth rate -- to each record. For the 29 percent of the sample whose firm has multiple locations or missing geographic information, the state-wide labor market conditions were assumed. ${ }^{9}$

In total, the data includes 31,596 workers injured between 1990:1 and 1995:4. Information on one or more of the data elements used in the analysis was missing for 511 workers, leaving an analytical sample of 31,085 injured workers. The injured workers were matched to 108,164 controls. Table 1 reports the number of controls per injured worker. One-half of the injured workers had at least five controls. Each worker contributes one observation for each of the 36 quarters of earnings data, 1990:1 to 1998:4.

Therefore, the regressions are based on 1,119,060 (36*31,085) observations.

\section{BASIC ESTIMATES OF EARNINGS LOSS}

Figure 4 displays the average earnings of the injured workers and the controls in each quarter relative to the quarter of injury. It is important to first understand the pattern of earnings among the uninjured controls. Earnings rise over the quarters leading up to the quarter of injury and then fall after injury. This

\footnotetext{
${ }^{8}$ At the same time, as note above, the WCIRB data do not include workers injured at self-insured firms, which accounts for roughly one-third of all claimants in California. This will cause our sample to under-represent workers in larger firms because the self-insured firms are exclusively large employers.

${ }^{9} \mathrm{We}$ included an indicator variable in the models that takes the value of one if this information is missing and zero otherwise.
} 
pattern is an artifact of the requirement that the controls (and the injured workers) must be working in the quarter of injury. The farther away from the quarter of injury - both before and after injury - the less likely they are to work because of typical movements in and out of the labor force. A simple thought experiment makes this point clear. Consider taking a random sample of 100 people who are working today. If we followed these 100 workers into the future and back into time, we would see that the share who were working would decline the further we moved away from today they retired, had children, entered school, becoming unemployed, or, for a variety of other reasons, had left employment or had not yet entered employment. This pattern in employment is depicted in Figure 5.

The second point to take away from Figure 4 is that the controls are a close match to the injured workers. Recall that matching was made on earnings in the four quarters prior to injury. However, earnings and employment of injured workers and their controls (Figures $4 \& 5$ ) are virtually identical over the entire 4-5 years prior to injury. This pattern implies that the matching approach is successful because any systematic differences between injured workers and their controls would have generated differences in their earnings 4-5 years prior to injury.

Turning to the post-injury period, it is found that earnings losses for injured workers are large and sustained. Earnings drop to 60 percent of the earnings of controls in the quarter after injury. Earnings then begin to rebound relative to controls' earnings. However, the recovery is slow, and even five years after injury the quarterly earnings loss is $\$ 1,257$, or 72 percent of the earnings of controls.

The declines in quarterly earnings are in large part due to the fact that many injured workers spend time out of work (Figure 5). Just three quarters after injury, there is almost a 30 percentage point difference in employment between the injured and control workers. However, the employment gap declines over time to 25 percentage points two years after injury, 15 after three years, 11 after four years, and 9 after five years. Clearly a large share of the loss in quarterly earnings is due to the loss in employment. The drop in employment after 5 years is 15 percent of the employment rate among controls after five years. Therefore, approximately 60 percent of the 25 percent loss in earnings is accounted for by losses in employment. Indeed, since quarterly employment rates are a rough measure of employment, this is likely to be an underestimate of the extent to which earnings losses are driven by reduced employment.

\section{MODEL-BASED ESTIMATES}

Tables 2 and 3 contain the estimates of equation (3) and several variations on this specification for quarterly earnings loss and employment loss, respectively. We will discuss the two tables simultaneously. The first row in each table contains the dip, drop, and recovery for the basic model. The estimates imply 
that earnings "dipped" by $\$ 884$ in the quarter of injury. As expected, the "drop" of $\$ 2,249$ was about twice as large as the dip. Earnings then recovered in the subsequent period by an average of $\$ 48$ per quarter. As a result, the quarterly earnings loss of $\$ 2,249$ at the quarter after injury had fallen to $\$ 1,910$ two years after injury and $\$ 1,522$ four years after injury. Summed over quarter of injury and the 20 quarters after, the cumulative earnings loss is $\$ 37,046$.

The impact on quarterly earnings is largely due to changes in employment. Employment dropped by 25 percentage points, with recovery at a rate of 0.83 percentage points per quarter (Table 3 ). After 8 quarters the employment effect had been reduced to 20 percentage points, and after 16 quarters the gap had been reduced to 13 points. Note that the "dip" is close to zero by construction. That is, both the injured workers and the controls must be working in the at-injury firm in the quarter of injury. Therefore, the dependent variable always takes the value of 0 at the dip. But since the quarter prior to the quarter of injury is the reference group, and employment of injured and control workers are not identical in that quarter, the dip is identified. However, the effect of the dip is very small in all cases.

The remaining estimates in Tables 2 and 3 are based on expanded versions of the basic model where the earnings and employment losses were allowed to vary across characteristics. The left panel in each table reports estimates from models in which the given characteristic is interacted with dip, drop, and recovery by itself. The right panel contains estimates when all the characteristics are simultaneously interacted with dip, drop, and recovery. Therefore, each box within these tables reports estimates from separate regressions.

Next to the estimates of dip, drop, and recovery are simulated quarterly earnings and employment losses at 8 and 16 quarters following injury. The cumulative loss over the entire 5 years following injury is also reported. These estimates are linear combinations of the effects associated with drop and recovery. For example, the quarterly loss 8 quarters after injury is equal to the sum of the drop plus seven times the recovery. When dip, drop, and recovery are interacted with various characteristics on the left panel of the tables, the simulations require adding the main effect along with the marginal effect for the given group. The simulations based on the regression estimate reported on the right panel weight the effects by the average of the characteristics observed in the sample, with the employment growth rate centered around its average value observed in the sample. As a result, the estimate of earnings losses listed under employment growth -- \$1,910 - equals the earnings losses estimated when no interactions are included, i.e., the estimate in the first row of the left panel of Tables 2 . Therefore, comparisons of estimates across the two panels demonstrates the effects of adding control variables evaluated at the average value of all 
other factors. ${ }^{10}$

Severity of injury. Severity is based on the claimant's "disability rating," which ranges from 1 to 100 , with a rating of 100 denoting permanent total disability. The goal of the disability rating system is to measure the effects of the injury on the worker's ability to compete in the labor market, with more serious injuries and illnesses receiving higher ratings. Higher ratings in turn lead to higher benefits paid to the worker. For example, slight instability of one knee joint would receive a rating of 10 , while moderate paralysis on one side of the body would be rated 60 . California has a detailed schedule that translates a medical report describing specific conditions into a disability rating, with adjustments based on age and occupation of the worker. Therefore, given two workers of different ages experiencing the same injury and in the same occupation, the older worker will receive a higher rating and therefore higher benefits. The job of the "rater" is to translate the physician's report into a disability rating, taking into account the age and occupation of the worker. Not surprisingly, the medical report and the calculation of the rating are the target of extensive litigation.

Table 2 demonstrates that for workers with the least severe injuries (i.e., "main effect"), the dip was $\$ 715$, the drop was $\$ 1,364$, and earnings recovered by $\$ 32$ per quarter following injury. As a result, the quarterly earnings loss of the least severely injured workers had declined to $\$ 876$ by 16 quarters after injury. Similarly, employment "dropped" by 14.6 percentage points, and the gap was less than half that size -5.8 percentage points -16 quarters after injury. Over five years, this led to a cumulative loss of $\$ 21,809$.

As expected, workers with more severe injuries have substantially larger earnings losses. The workers in the top quartile of injuries by severity have an earnings drop of $\$ 2,466$ more than workers with the least severe injuries. However, their recovery is accelerated by $\$ 32$ per quarter. After 8 quarters the loss for these workers is $\$ 3,377$, which is three times as great as the loss for the least severely injured workers. The gap remains about threefold -- $\$ 2,859$ versus $\$ 876$-- even 16 quarters after injury.

Furthermore, adjusting for all other factors - pre-injury earnings, firm size, employment growth, year of injury, and industry - does not effect the relative size of the effect across workers; the gap 16 quarters after injury remains roughly threefold $(\$ 2,676$ versus $\$ 958)$.

Although the evidence suggests that workers with higher ratings have higher earnings losses, this is not the case throughout the entire distribution of disability ratings. Workers in the bottom two quintiles experience virtually the same 5-year cumulative earnings loss -- \$21,809 versus $\$ 22,629$-- despite their

10 In addition to the variables discussed, the regressions also included a control for differences across years of data in the probability that an early-closing claim was included in the database. This variable, called "level," is reported in tables 2 and 3 . See the appendix for further discussion. 
different ratings. But because of their higher disability ratings, the workers' compensation benefits received by workers in the second quintile are twice as large -- $\$ 3,238$ versus $\$ 6,381$. Therefore, the evidence suggests that the disability rating system is not equitable: different levels of compensation are provided to workers who experience the same loss in earnings.

Pre-injury earnings. Pre-injury earnings are the average weekly wages of the injured worker during the year prior to injury, as reported to the WCIRB. The workers with the highest weekly wages experience the largest effects on earnings in absolute terms, with a loss of $\$ 2,386$ after 16 quarters. The loss after 16 quarters for the lowest quintile earnings group is $\$ 766$. The difference in earnings loss is driven by the fact that a given decline in employment for higher earnings workers will lead to a larger loss, and not by differences in employment after injury; the effect of the injury on employment is actually slightly smaller among the highest-wage workers during the first couple years after injury, although by four years after injury the employment difference has reversed (10.3 versus 14.0). Therefore, despite greater earnings losses, higher-wage workers are more successful in remaining employed initially after injury, and this is true even after adjusting for severity of injury and all other factors. For example, the employment effect after 8 quarters when all factors are adjusted is 3.9 percentage points higher for the lowest-wage workers relative to the highest-wage workers (20.6 versus 16.3).

Industry \& firm size. There are many reasons why workers with similar injuries in different firms or industries may have different earnings and employment consequences. Some industries, such as mining and construction, may be more dependent upon physical labor, and injuries may be more likely to require a new occupation. In addition, there are differences across industries in the extent of unionization, in which job protections may lead to lower earnings losses, but when job changes occur, the union earnings premium may be lost. There may also be differences in earnings consequences depending upon firm size. Larger firms are usually higher paying, which we have already seen leads to larger losses. Larger firms also have more opportunities for modified or alternative work for disabled workers, or may be able to hold a pre-injury position open longer while a worker recovers. Larger firms are also more likely to be experience-rated, and therefore are likely to have more of an incentive to return injured workers to work (reducing temporary disability benefit payments).

We find significant differences in losses across industries. The largest losses are observed for workers in the highly physical and often unionized industries of mining and construction, who, 8 quarters after injury, have losses of $\$ 2,542$. Other highly unionized industries, such as durable manufacturing, transportation, communications, electric, gas, and sanitary services, also have relatively large earnings losses. The relatively high earnings losses among workers in highly unionized industries suggest that some of the reduction in earnings may be due to a loss in union premia. However, disparities across 
industries decline considerably when other differences are controlled for in the right panel. The range in two-year quarterly losses declined from \$1,341 (\$2,542 for Mining and construction versus \$1,201 for Agriculture) when other factors are not adjusted to just $\$ 597$ ( $\$ 2,121$ for Durable Manufacturing versus $\$ 1,524$ for Agriculture) when the other factors are accounted for. The differences are accounted for largely by the differences in earnings across industries.

In the right panel, we find some evidence that workers at larger firms have lower earnings and employment losses after controlling for other characteristics (including differences in pre-injury wages). For example, employment loss after 8 quarters is 23.3 percentage points for workers in the smallest firms but just 15.2 percentage points among workers in the largest firms. These differences may be driven by the availability of modified and alternate work and the emphasis on earlier return to work at experiencerated employers.

Local labor market conditions. We represent local economic conditions with the conditions that existed in the county of employment at the time of injury. Therefore, the indicator does not vary over time for a given worker. An alternative is to use the conditions in the county of employment in the quarter of observation. However, workers move across counties in search of better employment, which would suggest that the economic conditions in the current location is endogenous. Therefore, we do not use this approach. (There is also the practical problem that we do not have geographic information for people who are not working.) However, in addition to using fixed economic conditions in the county and time period of injury, we also estimated models where economic conditions were allowed to vary over time, but the conditions are measured for the county of employment at the time of injury. This approach side-steps the issue of endogenous migration, but at the same time is likely to under-estimate the effects of labor market conditions. Models were estimated using the unemployment rate and the employment growth rate. There was no association between earnings losses and the unemployment rate; therefore, the unemployment rate is excluded from the models presented below.

The estimates imply that earnings losses are just $\$ 70$ lower $(\$ 1,884$ minus $\$ 1,814)$ two years after injury if one is injured when the employment growth rate is increased by the difference between the $90^{\text {th }}$ and $10^{\text {th }}$ percentile of it's distribution within California counties between 1991 and 1995. And when other interactions are included in the model, the effect declines to $\$ 48(\$ 1,910$ to $\$ 1,862)$.

Adding to the model the time-varying employment growth rate (in the county of injury) does not change the basic story (not shown in the tables). The effects of time-invariant labor market conditions on earnings losses are virtually unchanged $(-263,-2119$, and 74.0 for the dip, drop, and recovery - not shown in the tables - versus $-267,-2137$, and 74.4), and the direct effect of the time-varying employment growth rate is very small and statistically insignificant. When employment loss is the outcome, the effects of 
time-invariant employment growth rate are virtually unchanged when time-varying employment growth rate is added to the model $(0,-17.7$, and 1.40 for the dip, drop, and recovery). The direct effect of timevarying labor market conditions on the "drop" is statistically significant (-15.9 with a t-statistic of 3.10), but the effect on recovery is very small and insignificant.

The estimates in Tables 2 and 3 identify the effects of economic conditions using variation over time or across counties. However, our data allow us to adjust for time-invariant county factors that may confound the observed relationship between labor market conditions and earnings loss. Therefore, in models not reported, we added county fixed effects by interacting county dummy variables with each of the dip, drop, and recovery variables. After adding county effects, we find that the effects of labor market conditions are somewhat muted. Specifically, the dip, drop, and recovery reported in the right panel of Table 2 falls from -267 (t-statistic of 0.26 ) to -119 (t-statistic of 0.11 ), from -2137 (t-statistic of 5.23) to -1700 (t-statistic of 4.09), and from 74.4 (t-statistic of 2.41) to 79.9 (t-statistic of 2.58). ${ }^{11}$ Therefore, the modest estimates of the effects of labor market conditions reported in Tables 5 and 6 are most likely overstatements of the true effects.

As shown in Table 3, workers who are least severely injured are most able to return to work. It may also be the case that the effect of labor market conditions varies by severity. For example, the ability of a worker with a severe condition, such as a spinal cord injury, to return to work is most likely overwhelmed by the effects of the injury itself; a robust labor market is not likely to substantially improve their ability to find employment. In fact, because uninjured co-workers are more likely to experience job separation themselves during a downturn, earnings losses may in fact be smaller for workers severely injured during a recession. To test this hypothesis, the employment growth rate was interacted with severity of injury. To adjust for severity-specific trends in losses, this expanded model also includes interactions of each severity quintile indictor and each year indicator, and the estimates are reported in Table 4.

Workers with the least severe injuries have lower employment and earnings losses if they are injured when the labor market is more robust. Specifically, the difference between the $10^{\text {th }}$ and the $90^{\text {th }}$ percentile of the quarterly employment growth rate is 0.03 . Using the coefficient estimate in Table 4 for the least severely injured workers, an increase in the employment growth rate equal to 0.03 implies earnings losses at the quarter of injury would be lowered by $\$ 131(4392 * 0.03)$, which is 9 percent of the average drop of $\$ 1,492$. Repeating this exercise for each severity group, we find that local economic conditions have the largest effect on the least severely injured, and have very little effect on the more 
severely injured workers. That is, the effects on the drop in earnings of a 0.03 increase in employment growth rate is +4 percent for the 2 nd severity quintile, -4 percent for the 3 rd quintiles, and -3 percent for the $4^{\text {th }}$ and $5^{\text {th }}$ quintiles.

The magnitude of the effect on employment among the least severely injured workers is somewhat smaller than the effect on earnings. An increase in the employment growth rate of 0.03 reduces the employment loss by 1.4 percentage points, which is equal to 4.8 percent of the average drop experienced by the workers with the least severe injuries (i.e., 29.3). Therefore, it appears that robust economic conditions not only reduces time out of work, but also enhances earnings conditional on employment. In general, we find very little evidence that labor market conditions alter employment or earnings for the more severely injured workers. To the extent that labor market conditions influence earnings losses, the effect is concentrated among workers with the least severe injuries.

Changes over time. There were several changes in the workers' compensation system during the 1990s. Therefore, year effects are included in the models, and they are interacted with the dip, drop, and recovery (Tables 2 and 3). The estimates demonstrate a significant decline in earnings loss. Workers injured in 1991 experienced a loss of $\$ 41,408$ over the five years after injury. For workers injured just four years later in 1994 , the five-year loss was $\$ 33,574$. Only a small share of the decline is due to the changing composition of injured workers over the period. When severity, industry, and all other factors are adjusted, cumulative earnings losses after five years still fell from $\$ 40,818$ to $\$ 34,041$.

Temporary total disability payments. All workers suffering from permanent partial injuries receive TTD payments. For workers injured in 1991, 1992, and 1993, the amount of the benefit was a function of their pre-injury weekly wage as depicted in Figure 6. In June of 1994, the amount of TTD benefits increased for workers with weekly wages above $\$ 504$. For example, consider two workers, both earning \$609 per week, but one was injured in June of 1993 and the other was injured in June of 1994. The worker injured in 1993 would receive monthly TTD payments of $\$ 336$, while the worker injured in 1994 would receive benefits of $\$ 406$, an increase of 21 percent. This increased benefit may lead workers to spend more time out of work. In the long run, more time to recover after injury may lower earnings losses. Alternatively, if more time out of work leads to diminished attachment to the labor force or depreciation of human capital, the rise in benefits may increase earnings losses in the long run.

We examine the effects of this change by making three modifications to the models reported in the right panel of Tables 2 and 3. First, we replace the year dummies with quarter of injury dummies (interacted with dip, drop, and recovery) in order to make sure that time trends are fully controlled.

\footnotetext{
${ }^{11}$ When county effects are included in the employment loss regressions, the drop and recovery fall from
} 
Second, we include a dummy variable for whether the injured worker's weekly wage was above $\$ 504$ (and interact this indicator with dip, drop, and recovery). Third, we interact this new dummy variable with an indicator for whether the injury occurred when the TTD benefits had been raised (again interacted with dip, drop, and recovery). This last variable allows us to examine whether earnings losses changed more for workers who received larger TTD benefits (i.e., workers who had average weekly wages of at least \$504) versus workers who did not (i.e., workers who had average weekly wages of less than \$504).

We find that the increase in TTD benefits resulted in a slightly smaller earnings loss, suggesting the improved recovery effect exceeds the diminished human capital effect, but none of the estimates are large or precisely estimated (Table 5). For example, the "drop" is $\$ 154$ smaller for people in the treatment group (i.e., wages of at least $\$ 609$ and injured after 1993), but the t-statistic is 1.19. It is perhaps not surprising that we find very little evidence that the TTD expansion in California affected employment and earnings. First, the increase in TTD benefits was a relatively modest 21 percent. Meyer, Viscusi, and Durbin (1995) examined TTD increases in Kentucky and Michigan that were roughly 70\%, and even these large increases caused time-out-of-work to increase by only 1-2 weeks. If the effects were the same magnitude in California as they were in Kentucky and Michigan, then the California expansion would be expected to increase time-out-of-work by just a few days. Empirically identifying an effect of this size using quarterly data would be nearly impossible.

\section{EFFECTS OF SPECIFIC INJURIES}

While this study has grouped all permanent partial disabilities together, different injuries can have profoundly different effects on the workers. We provide evidence on four injury types: lower back (including lumbar and lumbo-sacral), carpal tunnel, psychiatric and mental stress, and spinal cord. Lower back injuries are examined because they represent the single most common type of injury, accounting for 22 percent of all of the injuries in our sample. Carpal tunnel is analyzed because upper extremity musculoskeletal conditions represent a growing fraction of claims and recently were the focus of the Occupational Safety and Health Administrations' short-lived regulations on ergonomics. Psychiatric and mental illness claims are highly controversial, and in 1993 the law was changed to make it more difficult for claims of this type to be compensable. Finally, losses associated with spinal cord injuries are reported in order to compare estimates with recent evidence from Krueger and Kruse (1999). ${ }^{12}$

-17.24 (t-statistic of 3.39) to -12.85 (t-statistic of 2.59) and from 1.36 (t-statistic of 4.12) to 1.39 (t-statistic of 3.76).

${ }^{12}$ Our classification of injuries is based on the nature of the injury and the part of the body injured. Mental stress and carpal tunnel are identified based on the nature of the injury. Spinal cord and lower back are identified based on the part of the body injured. No worker with carpal tunnel or mental stress had lower back or spinal cord 
Table 6 reports estimates in similar format as those in the left columns of Tables 2 and 3. That is, controls for other factors such as severity are not included in the analyses because we wanted to capture the entire effect of type of injury. We find that the employment and earnings losses associated with each of these four types of injuries are more severe than the losses associated with the average of all other injuries. Over the five years after injury, workers with back injuries suffer earnings losses that are roughly 18 percent higher than the losses experienced by workers who were injured for all other reasons not explicitly listed in the table $(\$ 38,950$ versus $\$ 33,027)$. Earnings losses for workers suffering from carpal tunnel are very similar to the earnings losses for workers who suffer from lower back injuries. The largest losses are for workers with spinal cord injuries or mental stress. The earnings losses of workers suffering from mental stress/psychiatric problems, $\$ 60,476$ over five years, are nearly twice as high as the losses for workers suffering from other injuries. Moreover, these losses are even higher than the losses for workers with spinal cord injuries. Krueger and Kruse (1995) found that victims of spinal cord injuries experienced large losses, as we do, but they also found that the earnings of these workers did not recover following injury. We do in fact find that earnings and employment recover for these workers. The difference is likely due to the fact that our analysis is by design restricted to workers who had injuries that were "partial." Krueger and Kruse's study examined all spinal cord injuries, including cases in which the worker was never expected to return to work.

Equation (3) assumes that the gap in pre-injury earnings between controls and treatment are the same and virtually zero across all subgroups analyzed. That is, it assumes that the matching approach works even when estimating losses separately by, for example, severity of injury, industry, and type of injury. This assumption was tested by estimating separate models for each of the subgroups identified in the left panel of Table 2 . The only group for whom the pre-injury earnings 4-5 years prior to injury did not match were for workers experiencing carpal tunnel. As depicted in Figure 7, there was a systematic difference in earnings prior to injury, with injured workers having slightly higher earnings. This gap 3-5 years prior to injury may be due to the fact that carpal tunnel injuries are more common among women, and the comparison workers to which they are matched may have a higher fraction of men than the injured group (since gender was not available to us for matching). If the growth rate of earnings is lower for women, then the pre-injury earnings of the injured group will be higher. This also suggests that the earnings loss estimate for the carpal tunnel injuries is biased upward.

injuries. If an injury affects more than one part of the body, we cannot identify the parts that were affected. Therefore, our analysis of lower back and spinal cord victims is restricted to injuries affecting only the given part. 


\section{DISCUSSION AND CONCLUSIONS}

We have found that workers with permanent partial disability from a workplace injury experience large earnings losses because of their injury. Moreover, despite the fact that earnings rebound after an initial steep fall, four to five years after injury losses were equal to 25 percent of the earnings of uninjured workers. A large share of the loss is due to a decline in employment among the injured workers. Earnings losses are smaller for workers: with less severe injuries, lower pre-injury earnings, and employed in larger firms. Workers injured during periods of economic expansion experience lower earnings losses, particularly if their injury is less severe. However, this effect is modest in size. The expansion in TTD benefits in 1994 had no effect on earnings and employment losses. Furthermore, there is some evidence that the disability rating system is not equitable; that is, workers who end up experiencing similar earnings losses receive different disability ratings and, in turn, different amounts of benefits.

The estimates of losses associated with spinal cord injuries and mental stress were particularly large. Moreover, the analyses of specific injuries demonstrate the potential for using a model-based approach in determining benefits for claimants. The model derives an estimate of the actual losses experienced by workers with various characteristics, and the model could be used to more accurately target benefits to workers who are expected to experience the greatest losses.

Other recent studies including Boden and Galizzi (1999a, 1999b), and Biddle (1998) have also found large effects of workplace injuries. The emphasis in this study on workers with permanent partial disabilities highlights the most serious and sustained workplace injuries, and allows examination of a common gateway to disability (Reville et al, 2001).

It is useful to translate the estimate of individual earnings into aggregate state-wide and national losses. Annually, there were roughly 125,000 PPD claims in California in the late 1990s. The average cumulative loss over five years following injury was $\$ 37,046$ (in 1997 dollars, Table 2). Therefore, the aggregate annual loss associated with injuries that result in permanent partial disability over a five-year period in California was $\$ 4.6$ billion. Twelve percent of employment in the nation was in California in the early to mid-1990s. If claims and losses in the rest of the nation where in the same proportion as employment, then earnings losses associated with permanent partial workplace injuries for the nation as a whole would total roughly $\$ 38.3$ billion annually. Moreover, earnings losses are large and persistent well beyond five years after the injury occurred.

Finally, the analysis suggests that matching methods using large longitudinal earnings administrative data can be an effective tool to estimate earnings losses. The earnings of "treatments" and "controls" (who were selected from the same firm with similar earnings) were virtually identical even 4-5 years prior to injury. Since the earnings database used to select comparison workers is available in every 
state, given administrative data on "treatments," these methods may be usefully applied to estimate losses from other types of dislocation such as automobile injuries or crime victims. 


\section{REFERENCES}

Berkowitz, Monroe, and John F. Burton, Jr. (1987). Permanent Disability Benefits in Workers' Compensation, Kalamazoo, MI: W. E. Upjohn Institute for Employment Research.

Biddle, Jeff (1998). "Estimation and Analysis of Long Term Wage Losses and Wage Replacement Rates of Washington State Workers' Compensation Claimants," mimeo, Department of Economics, Michigan State University, August.

Boden, Leslie I., and Monica Galizzi (1999a). "Economic Consequences of Workplace Injuries: Lost Earnings and Benefit Adequacy," mimeo, Department of Environmental Health, Boston University.

Boden, Leslie I., and Monica Galizzi (1999b). "Income Losses of Women and Men Injured at Work," mimeo, Department of Environmental Health, Boston University, May.

Brown, Charles and James Medoff (1989). “The Employer Size-Wage Effect,” Journal of Political Economy 97(5): 1027-59.

Dehejia, Rajeev H. and Sadek Wahba (1996). "Causal Effects in Non-Experimental Studies: Reevaluating the Evaluation of Training Programs," mimeo, Harvard University.

Department of Health and Human Services (2000). TANF Program Expenditures in FY 1999 through the 4th Quarter. Available at http://www.acf.dhhs.gov/programs/ofs/data/q499/table-f.htm

Department of Labor (2001). SESI UI Statistics, Calendar Year 1999. Available at http://www.workforcesecurity.doleta.gov/unemploy/cy99_stat.asp.

Department of Labor (2000). Employer Costs for Employee Compensation, 1986-99, Bulletin 2526, Washington, DC. Available at http://www.bls.gov/ecthome.htm.

Heckman, James J., Hidehiko Ichimura, and Petra Todd (1997). "Matching as an Econometric Estimator," University of Pittsburgh Department of Economics Working Paper No. 315, July 1997.

Heckman, James J., and V. Joseph Hotz (1989). "Choosing Among Alternative Nonexperimental Methods for Estimating the Impact of Social Programs: The Case of Manpower Training," Journal of the American Statistical Association 84, December. 
Hirsch, Barry T., David A. MacPherson, and J. Michael Dumond (1997). "Workers' Compensation Recipiency in Union and Nonunion Workplaces," Industrial and Labor Relations Review 50: 213-236

Holland, Paul W. (1986). "Statistics and Causal Inference," Journal of the American Statistical Association 81: 945-970

Jacobson, L. S., R. J. Lalonde, and D. G. Sullivan (1993). "Earnings Losses of Displaced Workers," American Economic Review 83:685-709.

Krueger, Alan and Douglas Kruse. (1995). "Labor Market Effects of Spinal Cord Injuries in the Dawn of the Computer Age," Princeton University mimeo, October.

Lalonde, Robert (1986). "Evaluating the Econometric Evaluations of Training Programs," American Economic Review 76: 604-620

Meyer, Bruce, W. Kip Viscusi, and David L. Durbin (1995). "Workers' Compensation and Injury Duration: Evidence from a Natural Experiment," American Economic Review 85(3).

Reville, Robert T. (1999). “The Impact of a Disabling Workplace Injury on Earnings and Labor Force Participation," In The Creation and Analysis of Employer-Employee Matched Data, Eds J.C. Haltiwanger, J.I. Lane, J.R. Spletzer, J.J.M. Theeuwes, and K.R. Troske, Elsevier Science B.V.

Reville, Robert T., Suzanne Polich, Seth Seabury, and Elizabeth Giddens (2000). "Permanent Disability at Private, Self-Insured Firms: A Study of Earnings Loss, Replacement, and Return to Work for Worker's Compensation Claimants," RAND MR-1268.0-ICJ, August.

Reville, Robert T., Robert F. Schoeni, Jeremy Arkes and Monica Reti, (2001). "Workplace Injuries as a Pathway to Disability," RAND, mimeo.

Rubin, Donald. (1973). "Matching to Remove Bias in Observational Studies," Biometrics 29: 159-183

Rubin, Donald. (1979). "Using Multivariate Matched Sampling and Regression Adjustments to Control Bias in Observational Studies," Journal of the American Statistical Association 74: 318-329 


\section{Appendix: Linking WCIRB claims data to EDD earnings data.}

The first step for creating the linked administrative data used in this project was to send EDD a list of permanent disability claimant Social Security numbers obtained from the WCIRB. The WCIRB required insurers to report SSN beginning in 1993, but in 1991 and 1992, less than half of the claims have SSNs (41 percent in 1992 and 32 percent in 1991). Only if a claim is still open at the time of the 1993 report level can it have an SSN (i.e., claims that closed at the first report level for 1992 cannot have SSNs, or 15 percent of 1992 claims, and claims that closed by the second report level for 1991 cannot have SSNs, or 27 percent of claims). Even if the claim is open by the 1993 report level, while many reported SSNs, it was not required. The results using 1991 and 1992 data are therefore biased toward later closing claims To control for this, we included a variable for the report level ("level") at which the claim is closed in the regression. As seen in table 2, level has a significant effect on earnings losses. Later closing claims have considerably higher earnings losses.

Even if the SSN is present on the WCIRB data, it may not be valid. In this case, either earnings data will not be found on the EDD data, or if the SSN is commonly used fraudulently, the claim will be linked to multiple individuals on the EDD data. To minimize this problem, we eliminated claims with SSNs that appeared multiple times in the WCIRB data, and had three or more names and three or more birth dates. This eliminated less than 1 percent of the claims. The match rate of the remaining SSNs to the EDD data was very high. Out of 343,576 claims for accidents from 1991-1994 with valid Social Security Numbers on the WCIRB data, only $4.8 \%$ percent were not found on the Base Wage file or if found, did not have earnings within one year before the quarter of injury. An additional 0.7 percent of claims with more than 2 names in the quarter of injury on the EDD file were deemed invalid and deleted. In a few cases, there were earnings prior to the quarter of injury, but no earnings in the quarter of injury. In this case, the quarter of injury is reassigned to the last quarter with earnings prior to the injury, up to one year. There were $3.9 \%$ of claims adjusted in this manner. 
Figure 1. Hypothetical Earnings Loss of Injured Workers

Earnings

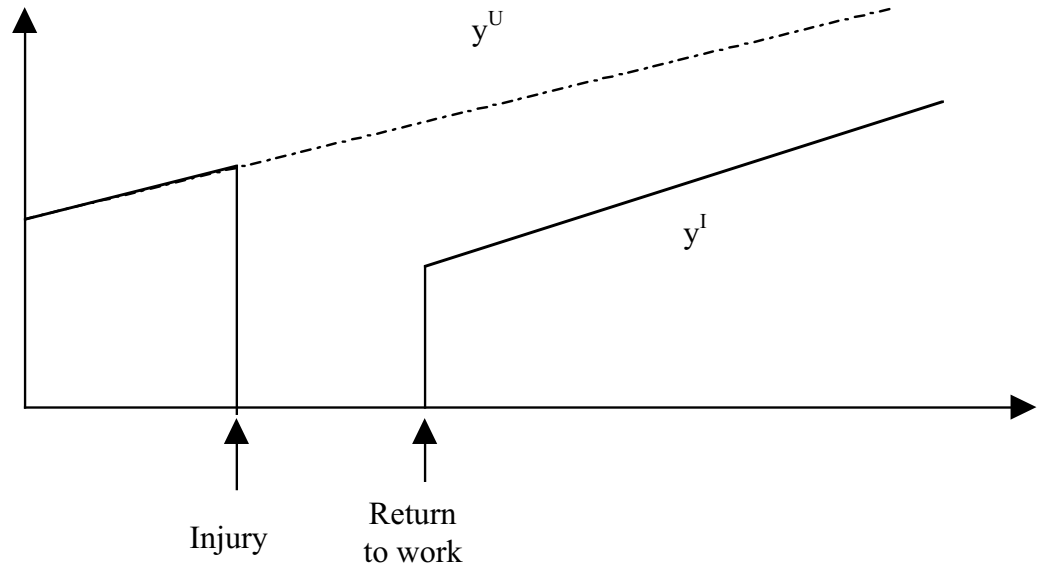


Figure 2. Earnings Loss Based on "Dip," "Drop," "Recovery" and Simple Mean Difference

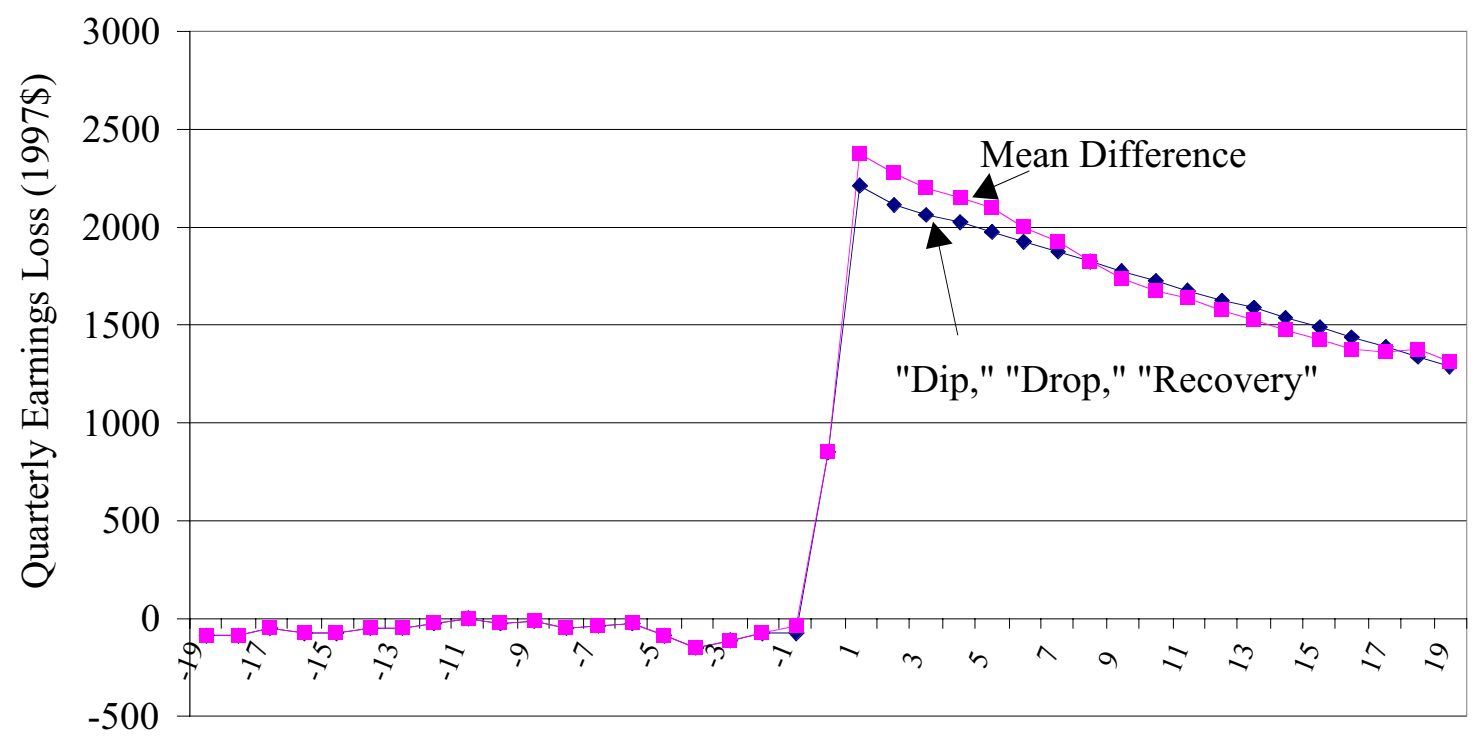

Quarters Since Injury 
Figure 3. Cross-State Migration for Recipients and Non-recipients of Workers' Compensation, 25-55 Years Old

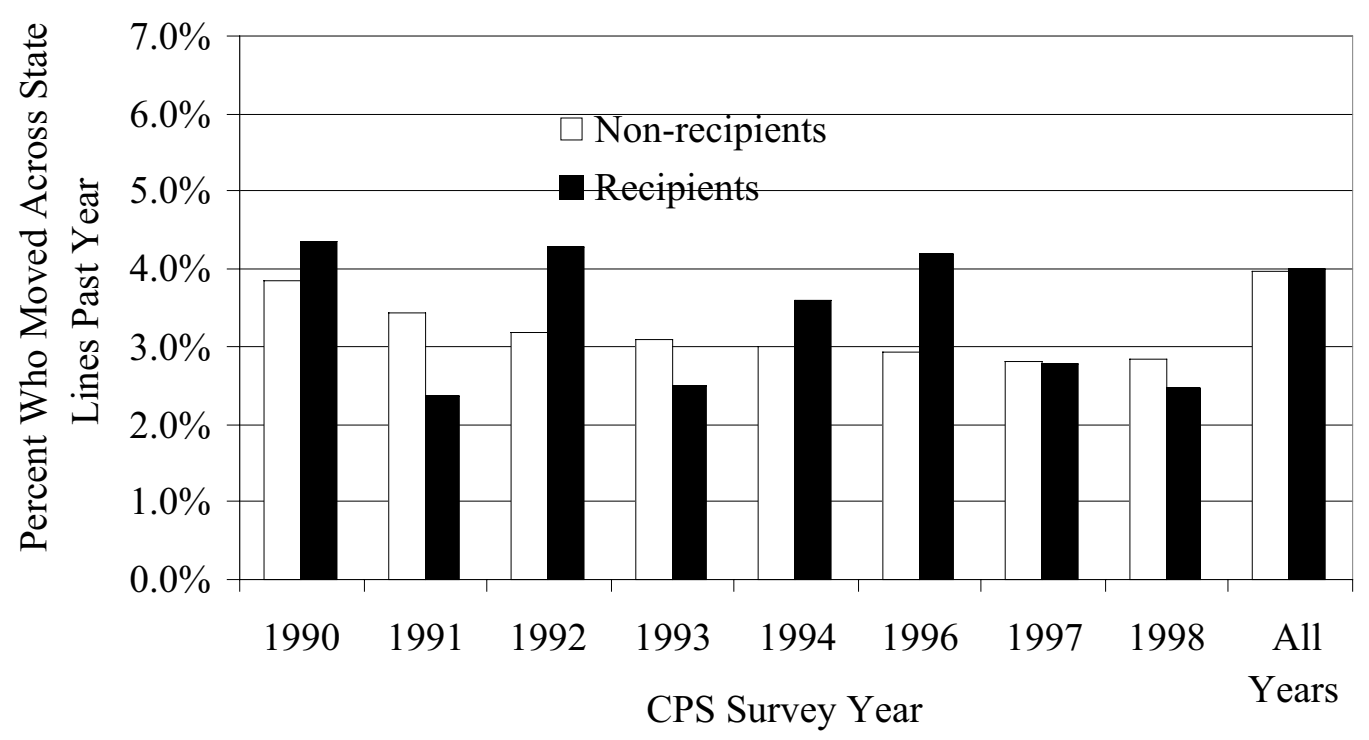

Source: Authors' tabulations based on March CPS.

1995 excluded because question in that year asked about migration in past 5 years. 
Figure 4. Average Earnings of Injured Workers and Their Controls by Quarters Since Injury

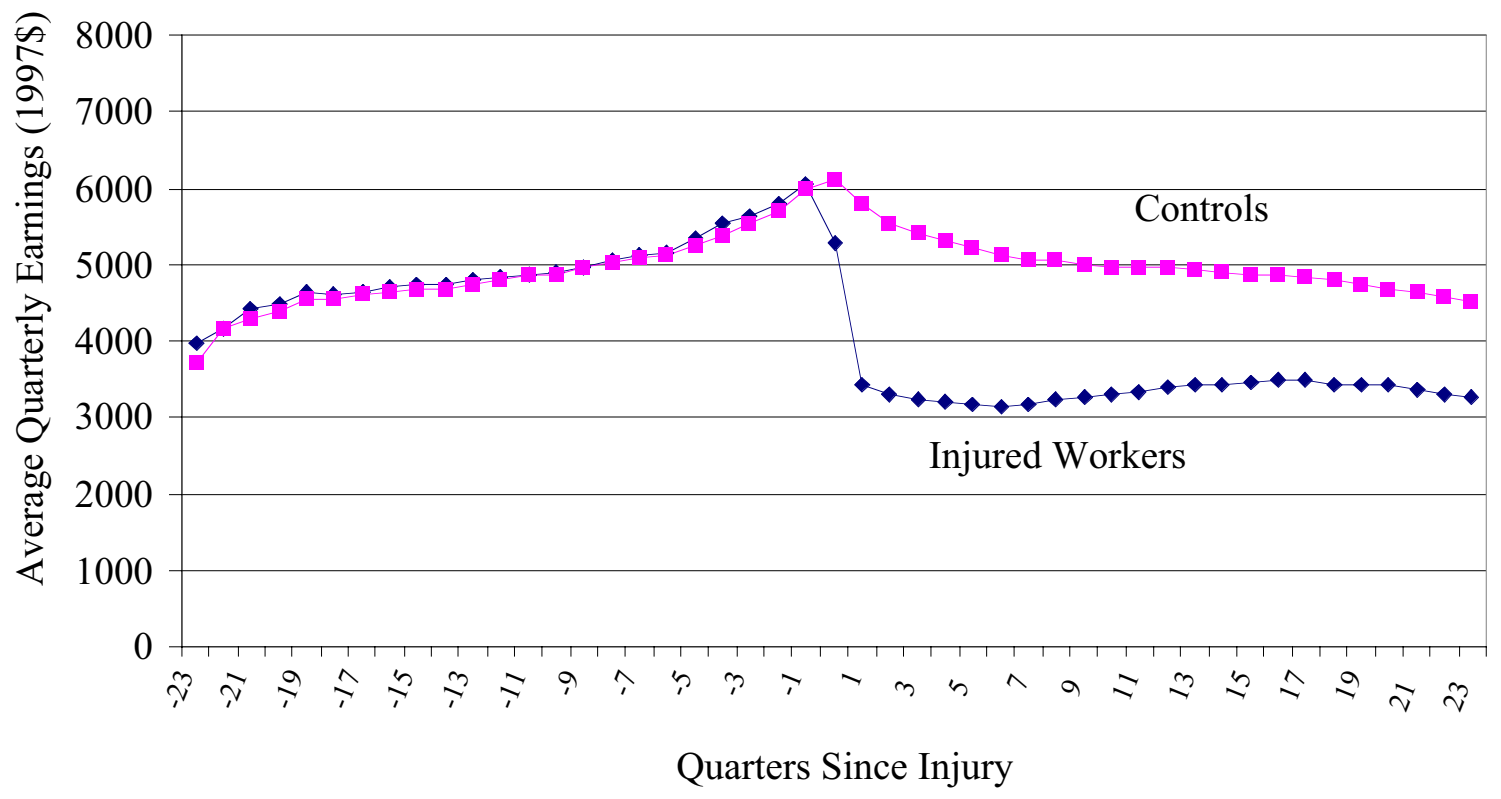


Figure 5. Employment of Injured Workers and Their Controls by Quarters Since Injury

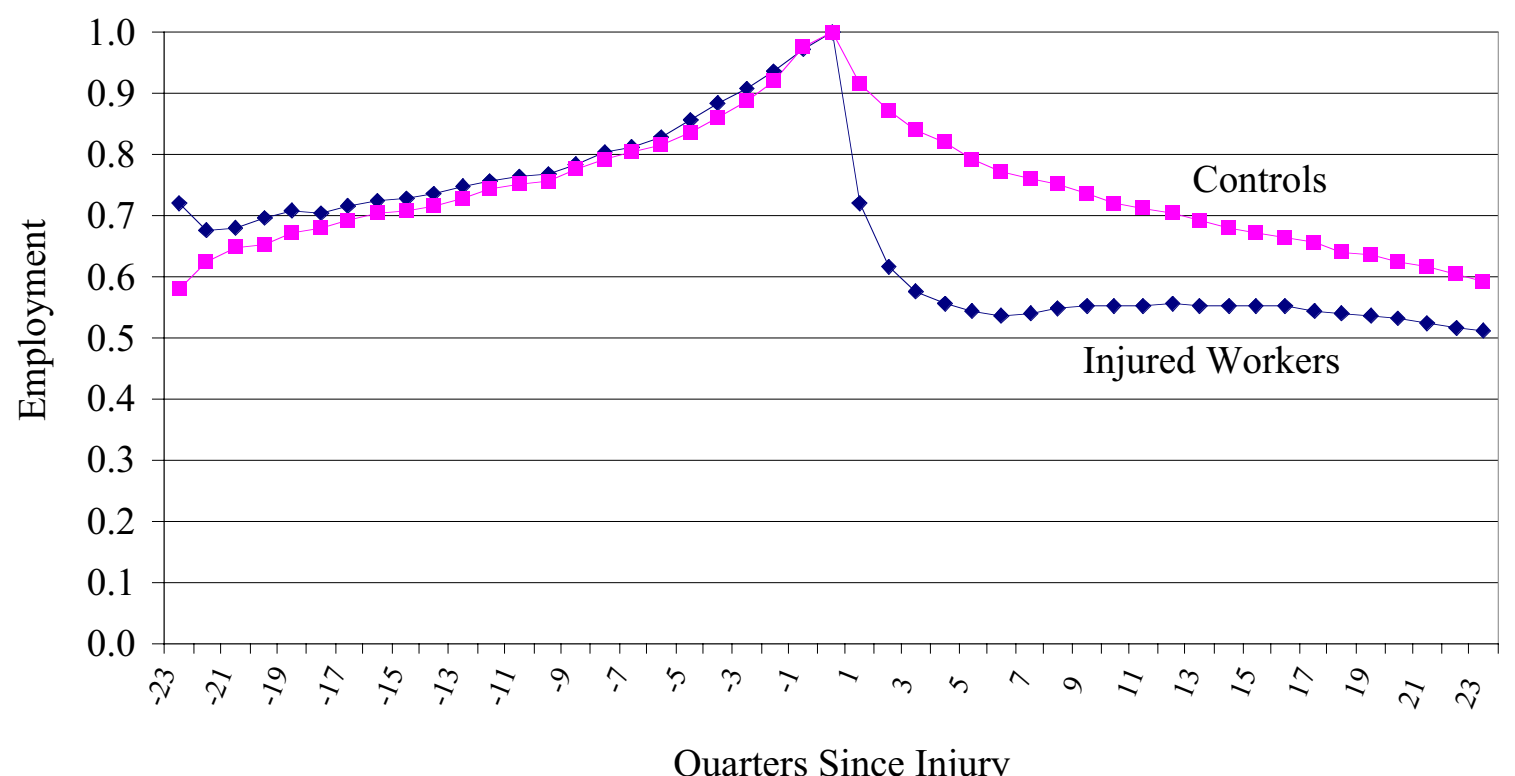

Quarters Since Injury 
Figure 6. Determination of Temporary Total Disability Benefits in California

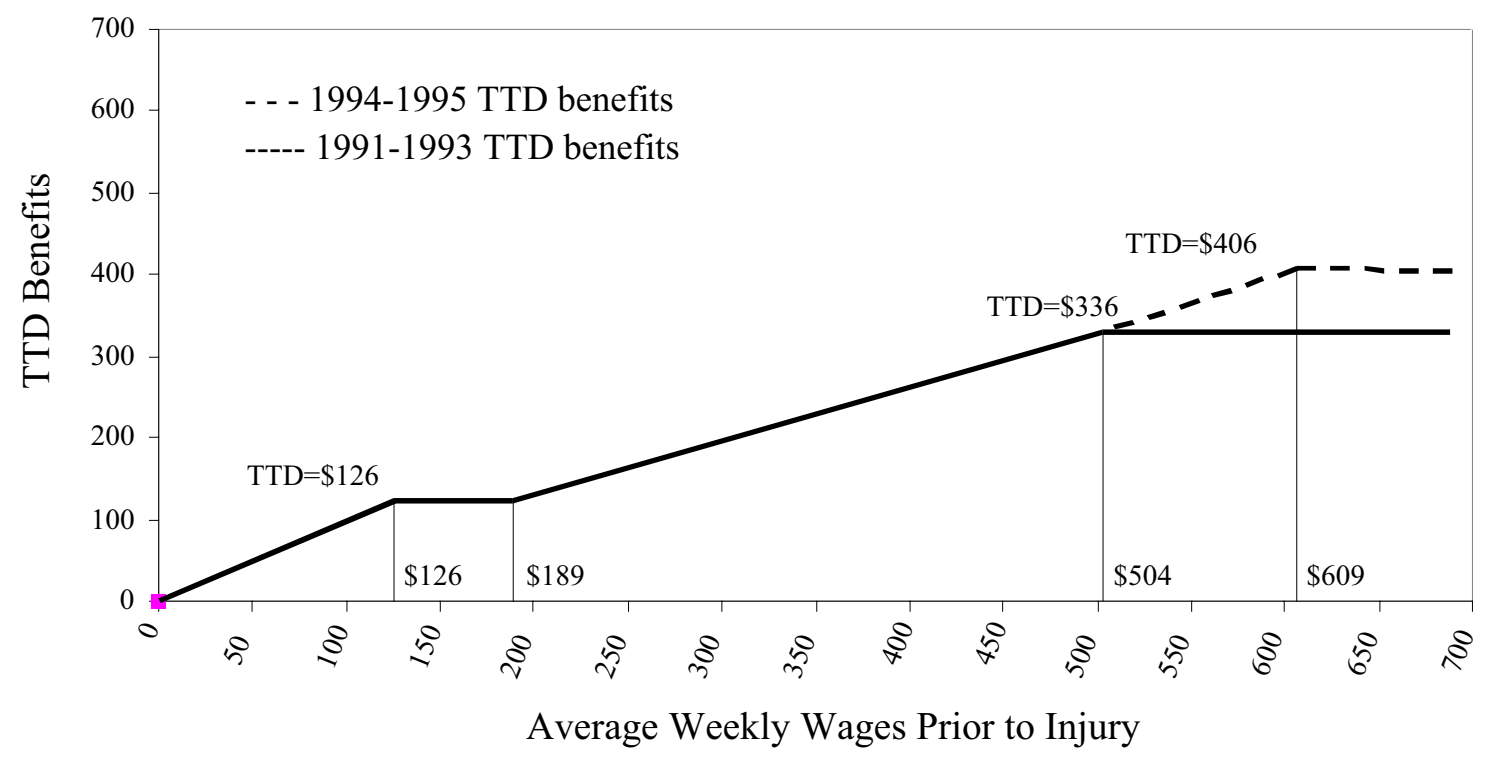


Figure 7. Earnings Loss For Carpal Tunnel

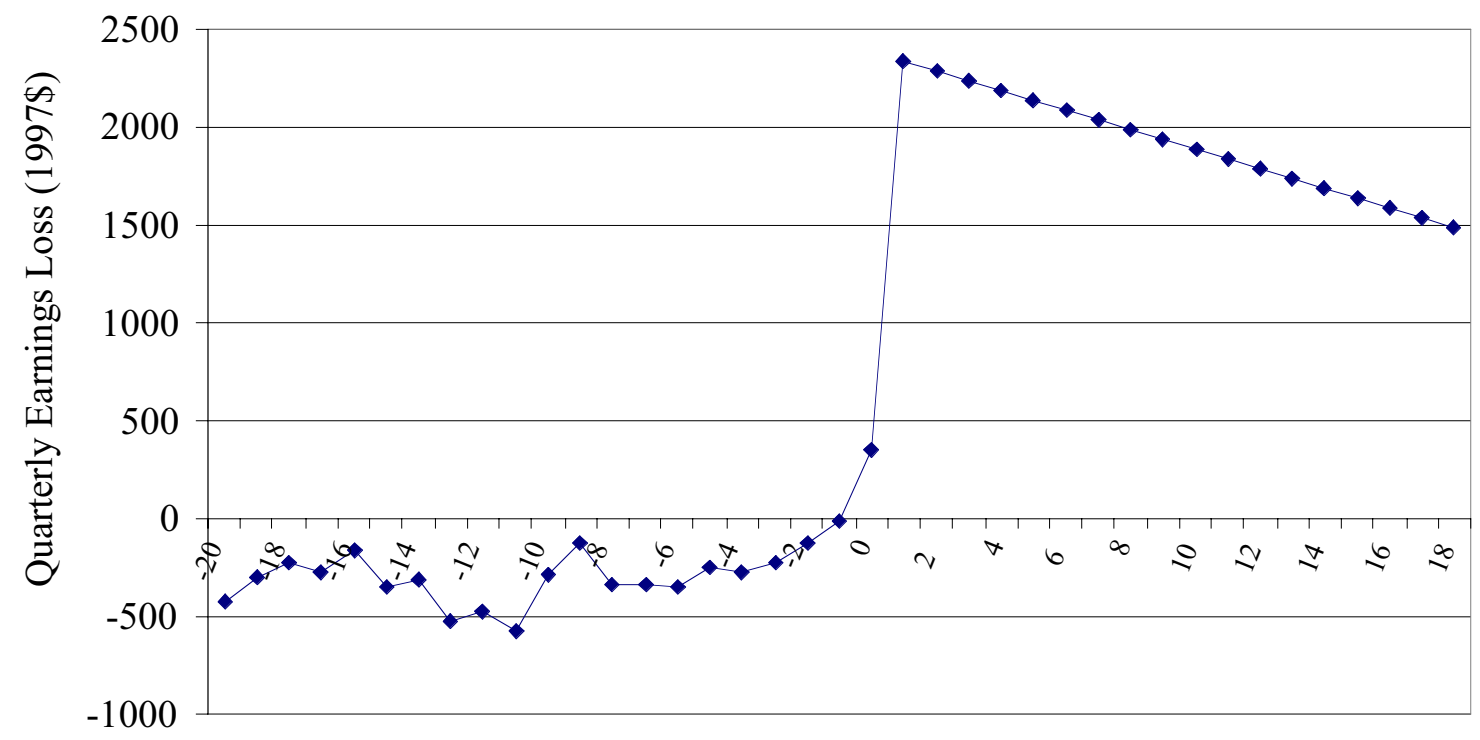

Quarters Since Injury 
Table 1. Distribution of Number of Controls per Injured Worker

\begin{tabular}{crr}
$\begin{array}{c}\text { Number of Controls } \\
\text { per Injured Worker }\end{array}$ & $\begin{array}{c}\text { Number of } \\
\text { Injured Workers }\end{array}$ & \multicolumn{2}{c}{$\begin{array}{c}\text { Proportion of } \\
\text { Injured Workers }\end{array}$} \\
\hline 1 & 5903 & 0.189 \\
2 & 5664 & 0.182 \\
3 & 5241 & 0.169 \\
4 & 4453 & 0.143 \\
5 & 3599 & 0.116 \\
6 & 2686 & 0.086 \\
7 & 1819 & 0.059 \\
8 & 1041 & 0.034 \\
9 & 502 & 0.016 \\
10 & 177 & 0.006 \\
\hline \hline
\end{tabular}




\begin{tabular}{|c|c|c|c|c|c|c|c|c|c|c|c|c|}
\hline \multicolumn{13}{|c|}{$\begin{array}{l}\text { Table 2. Quarterly Earnings Effect: Dip, Drop, and Recovery } \\
\text { (Each box represents one regression) }\end{array}$} \\
\hline & \multicolumn{6}{|c|}{ Without Other Interactions } & \multicolumn{6}{|c|}{ With Other Interactions } \\
\hline & \multirow[b]{2}{*}{ Dip } & \multirow[b]{2}{*}{ Drop } & \multirow[b]{2}{*}{ Recovery } & \multicolumn{2}{|c|}{ Earnings loss at: } & \multirow{2}{*}{$\begin{array}{c}\text { Cumulative loss } \\
\text { after } 5 \mathrm{yrs}\end{array}$} & \multirow[b]{2}{*}{ Dip } & \multirow[b]{2}{*}{ Drop } & \multirow[b]{2}{*}{ Recovery } & \multicolumn{2}{|c|}{ Earnings loss at: } & \multirow{2}{*}{$\begin{array}{c}\text { Cumulative los } \\
\text { after } 5 \text { yrs }\end{array}$} \\
\hline & & & & 8 qtrs & 16 qtrs & & & & & 8 Qrts & 16 Qrts & \\
\hline No interactions & $\begin{array}{c}884 \\
{[53.57]}\end{array}$ & $\begin{array}{c}2249 \\
{[91.99]}\end{array}$ & $\begin{array}{c}-48.5 \\
{[26.03]} \\
\end{array}$ & $\$ 1,910$ & $\$ 1,522$ & $\$ 37,046$ & & & & & & \\
\hline \multicolumn{13}{|c|}{\begin{tabular}{|l} 
Severity of injury quintile (disabilty rating) \\
\end{tabular}} \\
\hline Main effect (0-6 rating) & 715 & $\begin{array}{c}1364 \\
{[27.96]}\end{array}$ & $\begin{array}{l}-32.5 \\
{[8.46]}\end{array}$ & $\$ 1,136$ & $\$ 876$ & $\$ 21,809$ & $\begin{array}{c}750 \\
{[11.67]}\end{array}$ & $\begin{array}{c}1386 \\
{[14.41]}\end{array}$ & $\begin{array}{l}-29.4 \\
{[4.03]}\end{array}$ & $\$ 1,269$ & $\$ 958$ & $\$ 24,201$ \\
\hline 2nd lowest (6-11 rating) & $\begin{array}{c}25 \\
{[0.54]}\end{array}$ & $\begin{array}{c}59 \\
{[0.84]}\end{array}$ & $\begin{array}{c}-2.0 \\
{[0.35]}\end{array}$ & $\$ 1,181$ & $\$ 905$ & $\$ 22,629$ & $\begin{array}{c}19 \\
{[0.41]}\end{array}$ & $\begin{array}{c}-4 \\
{[0.07]}\end{array}$ & $\begin{array}{c}-1.4 \\
{[0.24]}\end{array}$ & $\$ 1,255$ & $\$ 934$ & $\$ 23,832$ \\
\hline 3rd lowest (11-20 rating) & $\begin{array}{l}116 \\
{[2.7]}\end{array}$ & $\begin{array}{c}488 \\
{[7.36]}\end{array}$ & $\begin{array}{l}-13.1 \\
{[2.35]}\end{array}$ & $\$ 1,533$ & $\$ 1,168$ & $\$ 29,312$ & $\begin{array}{c}95 \\
{[2.17]}\end{array}$ & $\begin{array}{c}371 \\
{[5.5]}\end{array}$ & $\begin{array}{l}-11.0 \\
{[1.96]}\end{array}$ & $\$ 1,563$ & $\$ 1,165$ & $\$ 29,692$ \\
\hline 4th lowest (20-31 rating) & $\begin{array}{c}239 \\
{[5.18]}\end{array}$ & $\begin{array}{c}1296 \\
{[18.63]}\end{array}$ & $\begin{array}{l}-26.6 \\
{[4.53]}\end{array}$ & $\$ 2,246$ & $\$ 1,773$ & $\$ 43,450$ & $\begin{array}{c}200 \\
{[4.16]}\end{array}$ & $\begin{array}{c}1090 \\
{[15.19]}\end{array}$ & $\begin{array}{l}-23.6 \\
{[3.94]}\end{array}$ & $\$ 2,194$ & $\$ 1,695$ & $\$ 42,150$ \\
\hline Most severe ( $>31$ rating) & $\begin{array}{c}449 \\
{[9.38]}\end{array}$ & $\begin{array}{c}2466 \\
{[34.71]}\end{array}$ & $\begin{array}{l}-32.2 \\
{[5.58]}\end{array}$ & $\$ 3,377$ & $\$ 2,859$ & $\$ 66,838$ & $\begin{array}{l}350 \\
{[6.9]}\end{array}$ & $\begin{array}{c}2120 \\
{[28.54]}\end{array}$ & $\begin{array}{l}-26.8 \\
{[4.46]}\end{array}$ & $\$ 3,201$ & $\$ 2,676$ & $\$ 63,093$ \\
\hline \multicolumn{13}{|l|}{ Pre-injury weekly wage quartile } \\
\hline Main effect $(<\$ 273)$ & $\begin{array}{c}558 \\
{[27.86]}\end{array}$ & $\begin{array}{c}1309 \\
{[41.05]}\end{array}$ & $\begin{array}{l}-36.2 \\
{[14.5]}\end{array}$ & $\$ 1,056$ & $\$ 766$ & $\$ 19,886$ & & & & $\$ 1,239$ & $\$ 892$ & $\$ 23,296$ \\
\hline 2nd lowest $(\$ 274-\$ 409)$ & $\begin{array}{c}221 \\
{[8.87]}\end{array}$ & $\begin{array}{c}580 \\
{[12.94]}\end{array}$ & $\begin{array}{l}-10.6 \\
{[2.64]}\end{array}$ & $\$ 1,561$ & $\$ 1,187$ & $\$ 29,833$ & $\begin{array}{c}207 \\
{[7.51]}\end{array}$ & $\begin{array}{c}415 \\
{[9.29]}\end{array}$ & $\begin{array}{c}-8.5 \\
{[2.19]}\end{array}$ & $\$ 1,595$ & $\$ 1,179$ & $\$ 30,218$ \\
\hline 3rd lowest $(\$ 409-\$ 598)$ & $\begin{array}{c}414 \\
{[12.41]}\end{array}$ & $\begin{array}{c}1279 \\
{[24.57]}\end{array}$ & $\begin{array}{l}-16.3 \\
{[4.28]}\end{array}$ & $\$ 2,221$ & $\$ 1,801$ & $\$ 43,326$ & $\begin{array}{c}339 \\
{[9.95]}\end{array}$ & $\begin{array}{l}1040 \\
{[19]}\end{array}$ & $\begin{array}{l}-15.6 \\
{[3.37]}\end{array}$ & $\$ 2,170$ & $\$ 1,698$ & $\$ 41,856$ \\
\hline Highest wages $(>\$ 598)$ & $\begin{array}{c}669 \\
{[14.66]} \\
\end{array}$ & $\begin{array}{c}1854 \\
{[26.5]}\end{array}$ & $\begin{array}{l}-15.5 \\
{[2.67]}\end{array}$ & $\$ 2,800$ & $\$ 2,386$ & $\$ 55,548$ & $\begin{array}{c}498 \\
{[10.49]}\end{array}$ & $\begin{array}{c}1456 \\
{[19.9]}\end{array}$ & $\begin{array}{c}-8.9 \\
{[1.45]}\end{array}$ & $\$ 2,633$ & $\$ 2,214$ & $\$ 51,994$ \\
\hline \multicolumn{13}{|l|}{ Firm size quartile } \\
\hline Main effect ( $<44$ employees) & $\begin{array}{c}1082 \\
{[38.09]}\end{array}$ & $\begin{array}{c}2283 \\
{[50.18]}\end{array}$ & $\begin{array}{c}-44.5 \\
{[12.08]}\end{array}$ & $\$ 1,972$ & $\$ 1,616$ & $\$ 38,602$ & & & & $\$ 2,016$ & $\$ 1,633$ & $\$ 39,319$ \\
\hline 2nd smallest (44-123 employees) & $\begin{array}{c}-164 \\
{[4.28]}\end{array}$ & $\begin{array}{c}-67 \\
{[1.06]}\end{array}$ & $\begin{array}{c}2.8 \\
{[0.55]}\end{array}$ & $\$ 1,925$ & $\$ 1,591$ & $\$ 37,791$ & $\begin{array}{c}-118 \\
{[3.08]}\end{array}$ & $\begin{array}{c}-50 \\
{[0.82]}\end{array}$ & $\begin{array}{c}2.9 \\
{[0.57]}\end{array}$ & $\$ 1,986$ & $\$ 1,626$ & $\$ 38,870$ \\
\hline 3rd smallest (123-400 employees) & $\begin{array}{c}-305 \\
{[7.61]}\end{array}$ & $\begin{array}{c}-113 \\
{[1.79]}\end{array}$ & $\begin{array}{c}-7.2 \\
{[1.38]}\end{array}$ & $\$ 1,808$ & $\$ 1,395$ & $\$ 34,717$ & $\begin{array}{c}-219 \\
{[5.23]}\end{array}$ & $\begin{array}{l}-109 \\
{[1.75]}\end{array}$ & $\begin{array}{c}-7.6 \\
{[1.39]}\end{array}$ & $\$ 1,854$ & $\$ 1,411$ & $\$ 35,445$ \\
\hline Largest firms ( $>400$ employees) & $\begin{array}{c}-320 \\
{[7.66]}\end{array}$ & $\begin{array}{c}39 \\
{[0.58]}\end{array}$ & $\begin{array}{c}-10.9 \\
{[1.99]}\end{array}$ & $\$ 1,934$ & $\$ 1,491$ & $\$ 37,134$ & $\begin{array}{c}-238 \\
{[4.98]}\end{array}$ & $\begin{array}{c}-159 \\
{[2.15]}\end{array}$ & $\begin{array}{c}-10.4 \\
{[1.67]}\end{array}$ & $\$ 1,784$ & $\$ 1,318$ & $\$ 33,799$ \\
\hline \multicolumn{13}{|l|}{ Employment growth rate } \\
\hline Main effect & $\begin{array}{c}927 \\
{[50.13]}\end{array}$ & $\begin{array}{c}2209 \\
{[79.34]}\end{array}$ & $\begin{array}{c}-46.3 \\
{[21.64]}\end{array}$ & $\$ 1,884$ & $\$ 1,514$ & $\$ 36,656$ & & & & $\$ 1,910$ & $\$ 1,497$ & $\$ 36,856$ \\
\hline Interaction & $\begin{array}{c}-398 \\
{[0.73]} \\
\end{array}$ & $\begin{array}{l}-2915 \\
{[3.49]} \\
\end{array}$ & $\begin{array}{c}82.4 \\
{[1.23]}\end{array}$ & $\$ 1,814$ & $\$ 1,595$ & $\$ 35,338$ & $\begin{array}{l}-267 \\
{[0.5]}\end{array}$ & $\begin{array}{c}-2137 \\
{[2.7]}\end{array}$ & $\begin{array}{l}74.4 \\
{[1.1]}\end{array}$ & $\$ 1,862$ & $\$ 1,448$ & $\$ 35,838$ \\
\hline \multicolumn{13}{|l|}{ Year of injury } \\
\hline Main effect (1991) & $\begin{array}{c}974 \\
{[28.3]}\end{array}$ & $\begin{array}{c}2548 \\
{[54.04]}\end{array}$ & $\begin{array}{c}-57.6 \\
{[20.77]}\end{array}$ & $\$ 2,145$ & $\$ 1,684$ & $\$ 41,408$ & & & & $\$ 2,118$ & $\$ 1,654$ & $\$ 40,818$ \\
\hline 1992 & $\begin{array}{c}-106.14 \\
{[2.33]}\end{array}$ & $\begin{array}{l}-249 \\
{[3.81]}\end{array}$ & $\begin{array}{c}4.49 \\
{[1.07]}\end{array}$ & $\$ 1,927$ & $\$ 1,502$ & $\$ 37,122$ & $\begin{array}{l}-122 \\
{[2.64]}\end{array}$ & $\begin{array}{c}-238 \\
{[3.74]}\end{array}$ & $\begin{array}{l}6.324 \\
{[1.48]}\end{array}$ & $\$ 1,924$ & $\$ 1,511$ & $\$ 37,148$ \\
\hline 1993 & $\begin{array}{l}-137 \\
{[3.13]}\end{array}$ & $\begin{array}{l}-326 \\
{[5.24]}\end{array}$ & $\begin{array}{l}8.119 \\
{[1.84]}\end{array}$ & $\$ 1,876$ & $\$ 1,480$ & $\$ 36,267$ & $\begin{array}{l}-161 \\
{[3.49]}\end{array}$ & $\begin{array}{l}-296 \\
{[4.73]}\end{array}$ & $\begin{array}{c}8.509 \\
{[1.8]}\end{array}$ & $\$ 1,881$ & $\$ 1,485$ & $\$ 36,389$ \\
\hline 1994 & $\begin{array}{c}-124.97 \\
{[2.92]}\end{array}$ & $\begin{array}{c}-443 \\
{[7.25]}\end{array}$ & $\begin{array}{l}6.993 \\
{[1.41]}\end{array}$ & $\$ 1,751$ & $\$ 1,346$ & $\$ 33,574$ & $\begin{array}{c}-157 \\
{[3.46]}\end{array}$ & $\begin{array}{l}-386 \\
{[6.15]}\end{array}$ & $\begin{array}{c}6.28 \\
{[1.17]}\end{array}$ & $\$ 1,776$ & $\$ 1,362$ & $\$ 34,031$ \\
\hline 1995 & $\begin{array}{c}-30 \\
{[0.51]}\end{array}$ & $\begin{array}{c}-358 \\
{[4.17]}\end{array}$ & $\begin{array}{c}15.8 \\
{[1.78]}\end{array}$ & $\$ 1,898$ & $\$ 1,563$ & $\$ 37,218$ & $\begin{array}{c}-64 \\
{[1.05]}\end{array}$ & $\begin{array}{c}-330 \\
{[3.93]}\end{array}$ & $\begin{array}{c}14.9 \\
{[1.64]}\end{array}$ & $\$ 1,892$ & $\$ 1,547$ & $\$ 37,011$ \\
\hline \multicolumn{13}{|l|}{ Level } \\
\hline Main effect & $\begin{array}{c}897 \\
{[46.83]}\end{array}$ & $\begin{array}{c}2522 \\
{[89.42]}\end{array}$ & $\begin{array}{c}-55.6 \\
{[26.66]}\end{array}$ & $\$ 2,132$ & $\$ 1,687$ & $\$ 41,268$ & & & & $\$ 2,004$ & $\$ 1,593$ & $\$ 38,846$ \\
\hline Early-closing claims & $\begin{array}{l}-226 \\
{[4.68]}\end{array}$ & $\begin{array}{l}-1467 \\
{[19.2]}\end{array}$ & $\begin{array}{l}38.3 \\
{[5.3]}\end{array}$ & $\$ 934$ & $\$ 795$ & $\$ 18,513$ & $\begin{array}{c}-58 \\
{[1.08]}\end{array}$ & $\begin{array}{c}-588 \\
{[7.03]}\end{array}$ & $\begin{array}{c}20.2 \\
{[2.57]}\end{array}$ & $\$ 1,557$ & $\$ 1,307$ & $\$ 30,733$ \\
\hline Medium-closing claims & $\begin{array}{c}38 \\
{[1.08]}\end{array}$ & $\begin{array}{c}-606 \\
{[10.66]}\end{array}$ & $\begin{array}{c}-1.7 \\
{[0.35]}\end{array}$ & $\$ 1,514$ & $\$ 1,055$ & $\$ 28,178$ & $\begin{array}{c}141 \\
{[3.81]}\end{array}$ & $\begin{array}{c}-64 \\
{[1.1]}\end{array}$ & $\begin{array}{l}-10.9 \\
{[2.12]}\end{array}$ & $\$ 1,864$ & $\$ 1,366$ & $\$ 35,225$ \\
\hline \multicolumn{13}{|l|}{\begin{tabular}{|l|} 
Industry \\
\end{tabular}} \\
\hline $\begin{array}{l}\text { Main effect (Durable } \\
\text { manufacturing) }\end{array}$ & $\begin{array}{c}931 \\
{[22.11]}\end{array}$ & $\begin{array}{c}2552 \\
{[40.34]}\end{array}$ & $\begin{array}{l}-49.2 \\
{[10.2]}\end{array}$ & $\$ 2,207$ & $\$ 1,814$ & $\$ 43,256$ & & & & $\$ 2,121$ & $\$ 1,723$ & $\$ 41,405$ \\
\hline Non-durable manufacturing & $\begin{array}{l}-135 \\
{[2.27]}\end{array}$ & $\begin{array}{l}-416 \\
{[4.57]}\end{array}$ & $\begin{array}{c}-0.4 \\
{[0.06]}\end{array}$ & $\$ 1,789$ & $\$ 1,392$ & $\$ 34,440$ & $\begin{array}{c}-62 \\
{[1.04]}\end{array}$ & $\begin{array}{c}-192 \\
{[2.17]}\end{array}$ & $\begin{array}{c}-0.9 \\
{[0.13]}\end{array}$ & $\$ 1,923$ & $\$ 1,518$ & $\$ 37,194$ \\
\hline Agriculture & $\begin{array}{c}-198 \\
{[3.36]}\end{array}$ & $\begin{array}{l}-1020 \\
{[11.78]}\end{array}$ & $\begin{array}{c}1.9 \\
{[0.29]}\end{array}$ & $\$ 1,201$ & $\$ 823$ & $\$ 22,241$ & $\begin{array}{c}-94 \\
{[1.63]}\end{array}$ & $\begin{array}{c}-558 \\
{[6.64]}\end{array}$ & $\begin{array}{c}-5.5 \\
{[0.83]}\end{array}$ & $\$ 1,524$ & $\$ 1,082$ & $\$ 28,532$ \\
\hline Mining \& construction & $\begin{array}{c}707 \\
{[9.38]}\end{array}$ & $\begin{array}{c}415 \\
{[3.83]}\end{array}$ & $\begin{array}{l}-11.4 \\
{[1.3]}\end{array}$ & $\$ 2,542$ & $\$ 2,057$ & $\$ 49,565$ & $\begin{array}{c}510 \\
{[6.61]}\end{array}$ & $\begin{array}{c}-90 \\
{[0.84]}\end{array}$ & $\begin{array}{l}-15.7 \\
{[1.73]}\end{array}$ & $\$ 1,921$ & $\$ 1,397$ & $\$ 36,218$ \\
\hline Transportation, etc. & $\begin{array}{c}215 \\
{[2.98]}\end{array}$ & $\begin{array}{c}76 \\
{[0.64]}\end{array}$ & $\begin{array}{l}-18.2 \\
{[1.86]}\end{array}$ & $\$ 2,155$ & $\$ 1,616$ & $\$ 41,014$ & $\begin{array}{l}159 \\
{[2.2]}\end{array}$ & $\begin{array}{l}-112 \\
{[0.97]}\end{array}$ & $\begin{array}{l}-17.6 \\
{[1.8]}\end{array}$ & $\$ 1,886$ & $\$ 1,347$ & $\$ 35,365$ \\
\hline Wholesale \& retail trade & $\begin{array}{l}-103 \\
{[2.12]}\end{array}$ & $\begin{array}{l}-445 \\
{[5.88]}\end{array}$ & $\begin{array}{c}1.8 \\
{[0.29]}\end{array}$ & $\$ 1,775$ & $\$ 1,395$ & $\$ 34,279$ & $\begin{array}{c}-43 \\
{[0.88]}\end{array}$ & $\begin{array}{l}-198 \\
{[2.65]}\end{array}$ & $\begin{array}{c}-2.0 \\
{[0.32]}\end{array}$ & $\$ 1,909$ & $\$ 1,495$ & $\$ 36,833$ \\
\hline Finance, insurance, real estate & $\begin{array}{c}-339 \\
{[4.22]}\end{array}$ & $\begin{array}{c}-180 \\
{[1.38]}\end{array}$ & $\begin{array}{c}3.5 \\
{[0.39]}\end{array}$ & $\$ 2,052$ & $\$ 1,687$ & $\$ 40,223$ & $\begin{array}{c}-314 \\
{[3.93]}\end{array}$ & $\begin{array}{c}-170 \\
{[1.36]}\end{array}$ & $\begin{array}{c}5.3 \\
{[0.52]}\end{array}$ & $\$ 1,988$ & $\$ 1,632$ & $\$ 38,940$ \\
\hline All other services & $\begin{array}{c}-252 \\
{[5.11]}\end{array}$ & $\begin{array}{l}-530 \\
{[6.86]}\end{array}$ & $\begin{array}{c}7.6 \\
{[1.22]}\end{array}$ & $\$ 1,730$ & $\$ 1,398$ & $\$ 33,719$ & $\begin{array}{l}-185 \\
{[3.76]}\end{array}$ & $\begin{array}{l}-303 \\
{[4.04]}\end{array}$ & $\begin{array}{c}5.2 \\
{[0.83]}\end{array}$ & $\$ 1,854$ & $\$ 1,498$ & $\$ 36,136$ \\
\hline
\end{tabular}

All models include variables in equation (3); that is, indicator variables for quarters from injury for quarters -20 to -1 . The "other interactions" included

in the models reported in the right panel are all those listed plus interactions of dip, drop, recovery with whether state-wide economic conditions were used to represent

county conditions and the level of the claim. t-statistic reported in brackets below coefficient estimate. Robust standard errors with clustering permitted within individuals over time.

*Simulated losses for time trend evaluated at 1991:1 (main effect) and 1994:1 (12 quarters after main effect). Interaction simulated at employment growth of 0.03 above the mean,

which is the difference between the 10th and 90th percentiles in the data. Number of observations equals $1,119,060$ 
Table 3. Quarterly Employment Effect: Dip, Drop, and Recovery

(Each box represents one regression)

\begin{tabular}{|c|c|c|c|c|c|c|c|c|c|c|}
\hline & \multicolumn{5}{|c|}{ Without Other Interactions } & \multicolumn{5}{|c|}{ With Other Interactions } \\
\hline & \multirow[b]{2}{*}{ Drop } & \multirow[b]{2}{*}{ Recovery } & \multicolumn{2}{|c|}{ Employ. loss at: } & \multirow{2}{*}{$\begin{array}{l}\% \text { of time out of } \\
\text { work over } 5 \text { yrs }\end{array}$} & \multirow[b]{2}{*}{ Drop } & \multirow[b]{2}{*}{ Recovery } & \multicolumn{2}{|c|}{ Employ. loss at: } & \multirow{2}{*}{$\begin{array}{l}\% \text { of time out of } \\
\text { work over } 5 \text { yrs }\end{array}$} \\
\hline & & & $8 \mathrm{qtrs}$ & 16 qtrs & & & & 8 Qrts & 16 Qrts & \\
\hline No interactions & $\begin{array}{c}25.34 \\
{[89.54]}\end{array}$ & $\begin{array}{c}-0.83 \\
{[39.73]} \\
\end{array}$ & 19.5 & 12.9 & $18 \%$ & & & & & \\
\hline \multicolumn{11}{|c|}{ Severity of injury quintile (disabilty rating) } \\
\hline Main effect (0-6 rating) & $\begin{array}{c}14.56 \\
{[24.93]}\end{array}$ & $\begin{array}{c}-0.59 \\
{[12.82]}\end{array}$ & 10.5 & 5.8 & $9 \%$ & $\begin{array}{c}27.91 \\
{[23.17]}\end{array}$ & $\begin{array}{c}-1.02 \\
{[11.28]}\end{array}$ & 10.7 & 5.4 & $9 \%$ \\
\hline 2nd lowest (6-11 rating) & $\begin{array}{c}0.88 \\
{[1.05]}\end{array}$ & $\begin{array}{c}-0.03 \\
{[0.51]}\end{array}$ & 11.1 & 6.2 & $10 \%$ & $\begin{array}{c}0.79 \\
{[0.95]}\end{array}$ & $\begin{array}{c}-0.04 \\
{[0.57]}\end{array}$ & 11.3 & 5.6 & $10 \%$ \\
\hline 3rd lowest (11-20 rating) & $\begin{array}{c}6.97 \\
{[8.73]}\end{array}$ & $\begin{array}{l}-0.29 \\
{[4.6]}\end{array}$ & 15.4 & 8.4 & $13 \%$ & $\begin{array}{c}6.53 \\
{[8.09]}\end{array}$ & $\begin{array}{c}-0.28 \\
{[4.33]}\end{array}$ & 15.3 & 7.8 & $13 \%$ \\
\hline 4th lowest (20-31 rating) & $\begin{array}{c}16.22 \\
{[19.75]}\end{array}$ & $\begin{array}{c}-0.40 \\
{[6.13]}\end{array}$ & 23.9 & 15.9 & $22 \%$ & $\begin{array}{c}15.82 \\
{[18.73]}\end{array}$ & $\begin{array}{c}-0.41 \\
{[6.06]}\end{array}$ & 23.7 & 15.1 & $22 \%$ \\
\hline Most severe (>31 rating) & $\begin{array}{c}28.36 \\
{[34.88]}\end{array}$ & $\begin{array}{c}-0.42 \\
{[6.35]}\end{array}$ & 35.9 & 27.8 & $34 \%$ & $\begin{array}{c}28.29 \\
{[33.28]}\end{array}$ & $\begin{array}{c}-0.45 \\
{[6.52]}\end{array}$ & 35.9 & 27.0 & $34 \%$ \\
\hline \multicolumn{11}{|l|}{ Pre-injury weekly wage quartile } \\
\hline Main effect $(<\$ 273)$ & $\begin{array}{c}25.79 \\
{[45.37]}\end{array}$ & $\begin{array}{c}-1.03 \\
{[23.75]}\end{array}$ & 18.6 & 10.3 & $16 \%$ & & & 20.6 & 11.4 & $18 \%$ \\
\hline 2nd lowest (\$274-\$409) & $\begin{array}{c}1.57 \\
{[2.01]}\end{array}$ & $\begin{array}{c}0.01 \\
{[0.23]}\end{array}$ & 20.2 & 12.1 & $18 \%$ & $\begin{array}{l}-0.36 \\
{[0.43]}\end{array}$ & $\begin{array}{c}0.05 \\
{[0.73]}\end{array}$ & 20.6 & 11.8 & $18 \%$ \\
\hline 3rd lowest $(\$ 409-\$ 598)$ & $\begin{array}{c}1.08 \\
{[1.41]}\end{array}$ & $\begin{array}{c}0.25 \\
{[4.12]}\end{array}$ & 21.4 & 15.1 & $20 \%$ & $\begin{array}{l}-2.03 \\
{[2.73]}\end{array}$ & $\begin{array}{c}0.30 \\
{[4.94]}\end{array}$ & 20.7 & 13.8 & $19 \%$ \\
\hline Highest wages (>\$598) & $\begin{array}{c}-4.46 \\
{[5.92]}\end{array}$ & $\begin{array}{c}0.54 \\
{[9.04]} \\
\end{array}$ & 17.9 & 14.0 & $17 \%$ & $\begin{array}{c}-8.80 \\
{[11.44]}\end{array}$ & $\begin{array}{c}0.64 \\
{[10.15]}\end{array}$ & 16.3 & 12.2 & $15 \%$ \\
\hline \multicolumn{11}{|l|}{ Firm size quartile } \\
\hline Main effect ( $<44$ employees) & $\begin{array}{c}29.43 \\
{[51.73]}\end{array}$ & $\begin{array}{c}-0.89 \\
{[19.91]}\end{array}$ & 23.2 & 16.0 & $22 \%$ & & & 23.3 & 15.6 & $21 \%$ \\
\hline 2nd smallest (44-123 employees) & $\begin{array}{l}-2.91 \\
{[3.80]}\end{array}$ & $\begin{array}{c}0.11 \\
{[1.88]}\end{array}$ & 21.1 & 14.8 & $20 \%$ & $\begin{array}{l}-2.76 \\
{[3.7]}\end{array}$ & $\begin{array}{c}0.12 \\
{[1.91]}\end{array}$ & 21.4 & 14.6 & $20 \%$ \\
\hline 3rd smallest (123-400 employees) & $\begin{array}{l}-5.37 \\
{[7.00]}\end{array}$ & $\begin{array}{c}0.06 \\
{[0.95]}\end{array}$ & 18.2 & 11.5 & $16 \%$ & $\begin{array}{l}-5.31 \\
{[6.89]}\end{array}$ & $\begin{array}{c}0.05 \\
{[0.74]}\end{array}$ & 18.3 & 11.0 & $16 \%$ \\
\hline Largest firms ( $>400$ employees) & $\begin{array}{c}-8.18 \\
{[10.74]}\end{array}$ & $\begin{array}{c}0.09 \\
{[1.54]}\end{array}$ & 15.6 & 9.2 & $14 \%$ & $\begin{array}{l}-8.41 \\
{[9.71]}\end{array}$ & $\begin{array}{c}0.04 \\
{[0.63]}\end{array}$ & 15.2 & 7.9 & $13 \%$ \\
\hline \multicolumn{11}{|l|}{ Employment growth rate } \\
\hline Main effect & $\begin{array}{c}26.52 \\
{[79.54]}\end{array}$ & $\begin{array}{c}-0.85 \\
{[33.92]}\end{array}$ & 20.6 & 13.8 & $19 \%$ & & & 19.6 & 12.3 & $18 \%$ \\
\hline Interaction & $\begin{array}{l}-23.85 \\
{[2.25]} \\
\end{array}$ & $\begin{array}{c}1.49 \\
{[1.78]} \\
\end{array}$ & 20.2 & 16.1 & $19 \%$ & $\begin{array}{l}-17.24 \\
{[1.67]}\end{array}$ & $\begin{array}{c}1.36 \\
{[1.63]}\end{array}$ & 19.3 & 12.1 & $17 \%$ \\
\hline \multicolumn{11}{|l|}{ Year of injury } \\
\hline Main effect (1991) & $\begin{array}{c}30.28 \\
{[52.40]}\end{array}$ & $\begin{array}{c}-0.98 \\
{[30.60]}\end{array}$ & 23.4 & 15.6 & $22 \%$ & & & 23.1 & 15.1 & $21 \%$ \\
\hline 1992 & $\begin{array}{c}-2.9043 \\
{[3.57]}\end{array}$ & $\begin{array}{l}0.152 \\
{[0.31]}\end{array}$ & 21.6 & 15.0 & $20 \%$ & $\begin{array}{c}-2.7637 \\
{[3.45]}\end{array}$ & $\begin{array}{l}0.0427 \\
{[0.85]}\end{array}$ & 20.7 & 13.0 & $19 \%$ \\
\hline 1993 & $\begin{array}{c}-5.7421 \\
{[7.52]}\end{array}$ & $\begin{array}{l}0.1213 \\
{[2.40]}\end{array}$ & 18.5 & 11.7 & $17 \%$ & $\begin{array}{c}-5.3424 \\
{[6.94]}\end{array}$ & $\begin{array}{l}0.1226 \\
{[2.27]}\end{array}$ & 18.7 & 11.6 & $17 \%$ \\
\hline 1994 & $\begin{array}{c}-7.3842 \\
{[9.89]}\end{array}$ & $\begin{array}{l}0.1427 \\
{[2.57]}\end{array}$ & 17.0 & 10.4 & $15 \%$ & $\begin{array}{c}-6.5836 \\
{[8.61]}\end{array}$ & $\begin{array}{l}0.1206 \\
{[2.00]}\end{array}$ & 17.4 & 10.4 & $15 \%$ \\
\hline 1995 & $\begin{array}{l}-7.08 \\
{[7.02]}\end{array}$ & $\begin{array}{c}0.24 \\
{[2.30]}\end{array}$ & 18.0 & 12.1 & $17 \%$ & $\begin{array}{l}-6.55 \\
{[6.57]}\end{array}$ & $\begin{array}{l}0.226 \\
{[2.14]}\end{array}$ & 18.2 & 12.0 & $17 \%$ \\
\hline \multicolumn{11}{|l|}{ Level } \\
\hline Main effect & $\begin{array}{l}28.62 \\
{[88.1]}\end{array}$ & $\begin{array}{c}-0.92 \\
{[39.23]}\end{array}$ & 22.2 & 14.9 & $20 \%$ & & & 21.9 & 14.6 & $20 \%$ \\
\hline Early-closing claims & $\begin{array}{l}-18.80 \\
{[22.03]}\end{array}$ & $\begin{array}{l}0.57 \\
{[7.1]}\end{array}$ & 7.4 & 4.6 & $7 \%$ & $\begin{array}{l}-8.31 \\
{[8.93]}\end{array}$ & $\begin{array}{c}0.35 \\
{[3.92]}\end{array}$ & 16.0 & 11.5 & $15 \%$ \\
\hline Medium-closing claims & $\begin{array}{l}-6.79 \\
{[9.81]}\end{array}$ & $\begin{array}{c}-0.07 \\
{[1.27]}\end{array}$ & 14.9 & 7.0 & $13 \%$ & $\begin{array}{l}-1.42 \\
{[2.01]}\end{array}$ & $\begin{array}{c}-0.15 \\
{[2.47]}\end{array}$ & 19.4 & 10.9 & $17 \%$ \\
\hline \multicolumn{11}{|l|}{ Industry } \\
\hline $\begin{array}{l}\text { Main effect (Durable } \\
\text { manufacturing) }\end{array}$ & $\begin{array}{c}25.34 \\
{[37.32]}\end{array}$ & $\begin{array}{c}-0.80 \\
{[15.47]}\end{array}$ & 19.7 & 13.3 & $18 \%$ & & & 20.2 & 13.2 & $18 \%$ \\
\hline Non-durable manufacturing & $\begin{array}{c}-1.07 \\
{[1]}\end{array}$ & $\begin{array}{c}0.02 \\
{[0.22]}\end{array}$ & 18.8 & 12.5 & $17 \%$ & $\begin{array}{l}-0.64 \\
{[0.62]}\end{array}$ & $\begin{array}{c}-0.11 \\
{[0.73]}\end{array}$ & 18.8 & 10.9 & $17 \%$ \\
\hline Agriculture & $\begin{array}{c}2.38 \\
{[1.85]}\end{array}$ & $\begin{array}{l}-0.27 \\
{[2.62]}\end{array}$ & 20.2 & 11.7 & $18 \%$ & $\begin{array}{l}-0.39 \\
{[0.31]}\end{array}$ & $\begin{array}{c}-0.27 \\
{[1.09]}\end{array}$ & 17.9 & 8.9 & $15 \%$ \\
\hline Mining \& construction & $\begin{array}{c}3.79 \\
{[3.47]}\end{array}$ & $\begin{array}{l}-0.12 \\
{[1.35]}\end{array}$ & 22.7 & 15.4 & $21 \%$ & $\begin{array}{c}1.63 \\
{[1.51]}\end{array}$ & $\begin{array}{l}-0.27 \\
{[3.00]}\end{array}$ & 20.0 & 10.9 & $17 \%$ \\
\hline Transportation, etc. & $\begin{array}{l}-2.02 \\
{[1.6]}\end{array}$ & $\begin{array}{c}0.06 \\
{[0.56]}\end{array}$ & 18.1 & 12.2 & $17 \%$ & $\begin{array}{l}-2.06 \\
{[1.70]}\end{array}$ & $\begin{array}{c}0.00 \\
{[0.04]}\end{array}$ & 18.2 & 11.2 & $16 \%$ \\
\hline Wholesale \& retail trade & $\begin{array}{c}0.75 \\
{[0.87]}\end{array}$ & $\begin{array}{l}-0.06 \\
{[0.9]}\end{array}$ & 20.1 & 13.2 & $18 \%$ & $\begin{array}{c}0.34 \\
{[0.40]}\end{array}$ & $\begin{array}{l}-0.01 \\
{[0.15]}\end{array}$ & 20.5 & 13.4 & $19 \%$ \\
\hline Finance, insurance, real estate & $\begin{array}{l}-1.99 \\
{[1.51]}\end{array}$ & $\begin{array}{c}0.05 \\
{[0.45]}\end{array}$ & 18.1 & 12.0 & $17 \%$ & $\begin{array}{l}-0.70 \\
{[0.55]}\end{array}$ & $\begin{array}{c}0.02 \\
{[0.24]}\end{array}$ & 19.7 & 12.9 & $18 \%$ \\
\hline All other services & $\begin{array}{c}-1.34 \\
{[1.55]} \\
\end{array}$ & $\begin{array}{c}0.00 \\
{[0.01]}\end{array}$ & 18.4 & 12.0 & $17 \%$ & $\begin{array}{l}-1.37 \\
{[1.63]}\end{array}$ & $\begin{array}{c}0.05 \\
{[0.75]}\end{array}$ & 19.2 & 12.6 & $18 \%$ \\
\hline
\end{tabular}

All models include variables in equation (3); that is, indicator variables for quarters from injury for quarters -20 to -1 . The "other interactions" included

in the models reported in the right panel are all those listed plus interactions of dip, drop, recovery with whether state-wide economic conditions were used to represent

county conditions and the level of the claim. t-statistic reported in brackets below coefficient estimate. Robust standard errors with clustering permitted within individuals ove *Simulated losses for time trend evaluated at 1991:1 (main effect) and 1994:1 (12 quarters after main effect). Interaction simulated at employment growth of 0.03 above the 1 which is the difference between the 10th and 90th percentiles in the data. Number of observations equals 1,119,060. 
Table 4. Interaction of Employment Growth and Severity of Injury

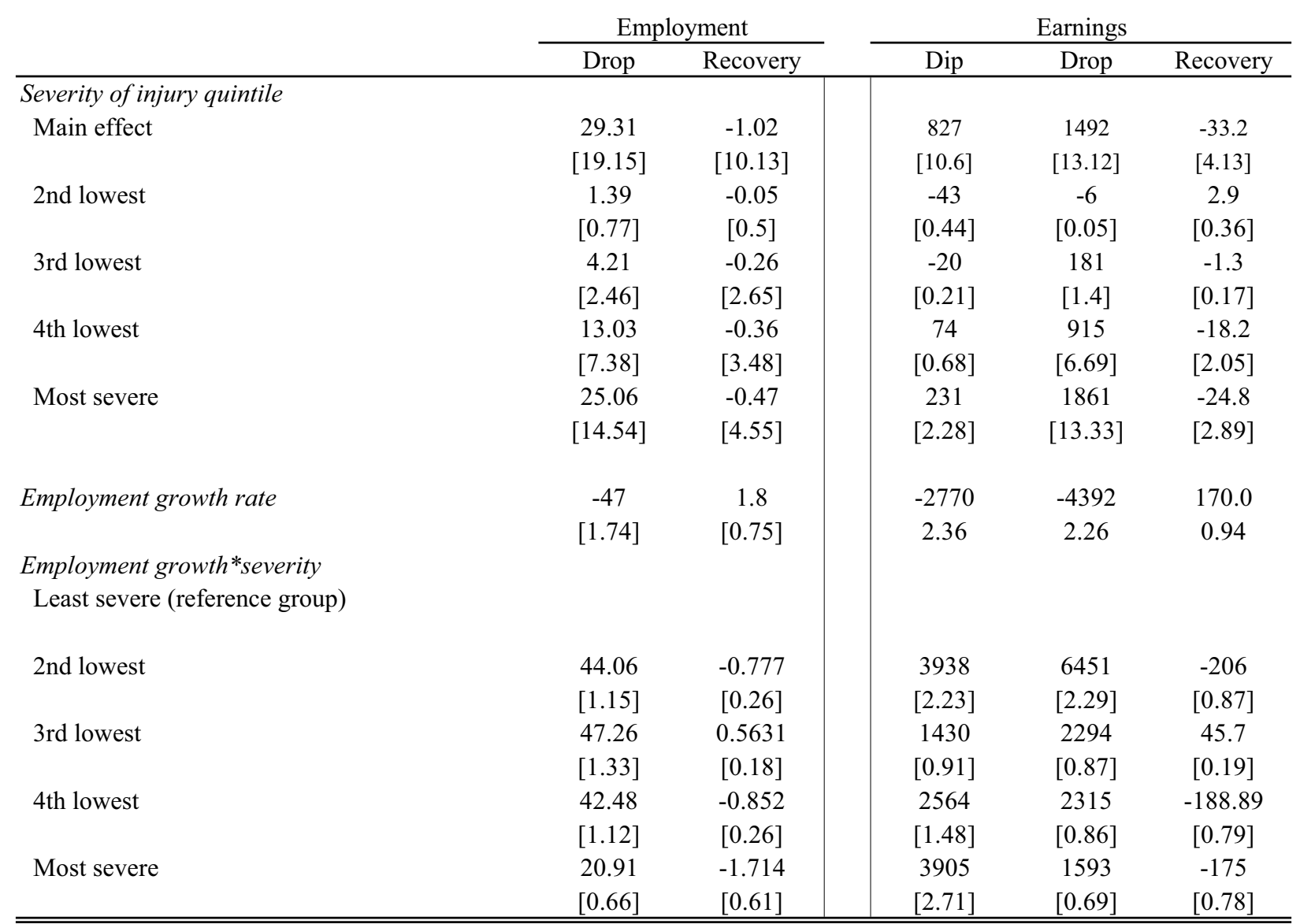

Both models also include all variables listed in the right-side panel of Table 2 plus severity quintiles interacted with year dummies. Number of observations in the regressions equals 1,119,060. Absolute value of t-statistic reported in brackets Robust standard errors with clustering permitted within individuals over time. 
Table 5. Effects of Change in TTD Benefits

\begin{tabular}{lcc|cccc} 
& \multicolumn{2}{c}{ Employment } & \multicolumn{3}{c}{ Earnings } \\
\cline { 2 - 6 } & & & & & \\
& Drop & Recovery & Dip & Drop & Recovery \\
\hline \multirow{2}{*}{ Main effect } & & & & & \\
& 28.98 & -1.00 & 699 & 1568 & -34.0 \\
Weekly wage $>\$ 504$ & {$[18.53]$} & {$[9.52]$} & {$[7.93]$} & {$[12.20]$} & {$[3.95]$} \\
& -2.23 & 0.10 & 92 & 497 & -19.5 \\
Policy change*weekly wage $>\$ 504$ & {$[1.78]$} & {$[1.00]$} & {$[1.16]$} & {$[4.02]$} & {$[1.82]$} \\
& 0.67 & 0.11 & -70 & -154 & 6.8 \\
& {$[0.56]$} & {$[0.91]$} & {$[0.76]$} & {$[1.19]$} & {$[0.50]$} \\
\hline \hline
\end{tabular}

Both models also include all variables in the models reported in the right-hand panel of Tables 2 and 3 except that the year indicators have been replaced with quarter indicators. Absolute value of t-statistic reported in brackets. Robust standard errors with clustering permitted within individuals over time. 
Table 6. Dip, Drop, and Recovery by Type of Injury

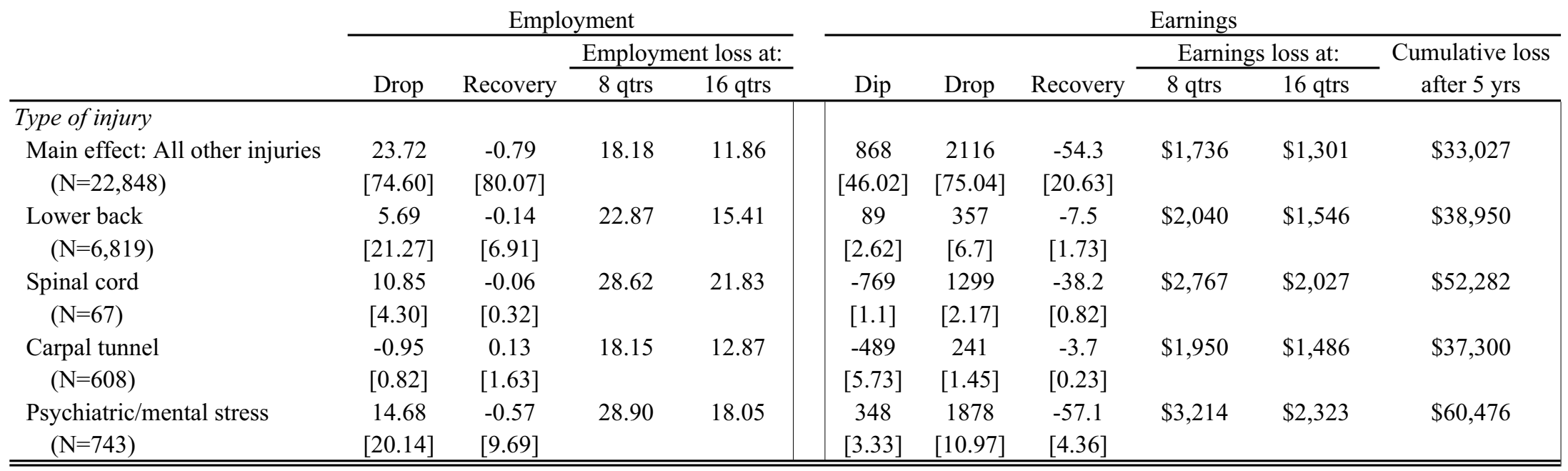

Both models also include indicator variables for quarters from injury for quarters -20 to -1 .

Absolute value of t-statistic reported in brackets. Robust standard errors with clustering permitted within individuals over time.

$\mathrm{N}$ is the number of workers with the given type of injury. Number of observations in the regressions equals $1,119,060$. 
Table A1. Comparison of Injured Workers Who Could and Could Not be Matched to Controls Matched to Controls Not Matched to Controls

\begin{tabular}{lcc}
\hline $\begin{array}{l}\text { Number of observations } \\
\text { Pre-injury average weekly wages }\end{array}$ & 31,085 & 15,609 \\
Mean & $\$ 467$ & $\$ 427$ \\
Median & $\$ 409$ & $\$ 353$ \\
Firm size & & \\
Mean & 1,227 & 2,905 \\
Median & 123 & 65 \\
$75^{\text {th }}$ percentile & 400 & 793 \\
Disability rating & & \\
Mean & 20.0 & 19.5 \\
Median & 15.0 & 15.0 \\
Industry of employment when injured & & \\
Durable manufacturing & $15 \%$ & $12 \%$ \\
Non-durable manufacturing & $10 \%$ & $7 \%$ \\
Agriculture & $6 \%$ & $7 \%$ \\
Mining \& construction & $10 \%$ & $13 \%$ \\
Transportation, etc. & $6 \%$ & $6 \%$ \\
Wholesale and retail trade & $24 \%$ & $24 \%$ \\
Finance, insurance, \& real estate & $6 \%$ & $5 \%$ \\
All other services & $25 \%$ & $26 \%$ \\
\hline \hline
\end{tabular}


Table A2. Simulated Earnings Loss by Quarter of Injury for Matched, Unmatched, and Entire Sample

\begin{tabular}{|c|c|c|c|c|}
\hline \multirow{4}{*}{$\begin{array}{l}\text { Quarters from } \\
\text { Injury }\end{array}$} & \multicolumn{3}{|c|}{ Simulated Earnings Loss } & \multirow{4}{*}{$\begin{array}{c}\text { Relative } \\
\text { Loss } \\
(1) /(3)\end{array}$} \\
\hline & Matched & Unmatched & Entire & \\
\hline & Sample & Sample & Sample & \\
\hline & (1) & (2) & (3) & \\
\hline 1 & $\$ 2,220$ & $\$ 2,099$ & $\$ 2,180$ & $101.9 \%$ \\
\hline 2 & $\$ 2,168$ & $\$ 2,048$ & $\$ 2,128$ & $101.9 \%$ \\
\hline 3 & $\$ 2,117$ & $\$ 1,997$ & $\$ 2,077$ & $101.9 \%$ \\
\hline 4 & $\$ 2,065$ & $\$ 1,945$ & $\$ 2,025$ & $102.0 \%$ \\
\hline 5 & $\$ 2,013$ & $\$ 1,894$ & $\$ 1,974$ & $102.0 \%$ \\
\hline 6 & $\$ 1,962$ & $\$ 1,843$ & $\$ 1,922$ & $102.1 \%$ \\
\hline 7 & $\$ 1,910$ & $\$ 1,792$ & $\$ 1,871$ & $102.1 \%$ \\
\hline 8 & $\$ 1,858$ & $\$ 1,741$ & $\$ 1,819$ & $102.2 \%$ \\
\hline 9 & $\$ 1,807$ & $\$ 1,690$ & $\$ 1,768$ & $102.2 \%$ \\
\hline 10 & $\$ 1,755$ & $\$ 1,639$ & $\$ 1,716$ & $102.3 \%$ \\
\hline 11 & $\$ 1,703$ & $\$ 1,588$ & $\$ 1,665$ & $102.3 \%$ \\
\hline 12 & $\$ 1,652$ & $\$ 1,536$ & $\$ 1,613$ & $102.4 \%$ \\
\hline 13 & $\$ 1,600$ & $\$ 1,485$ & $\$ 1,562$ & $102.5 \%$ \\
\hline 14 & $\$ 1,548$ & $\$ 1,434$ & $\$ 1,510$ & $102.5 \%$ \\
\hline 15 & $\$ 1,497$ & $\$ 1,383$ & $\$ 1,459$ & $102.6 \%$ \\
\hline 16 & $\$ 1,445$ & $\$ 1,332$ & $\$ 1,407$ & $102.7 \%$ \\
\hline 17 & $\$ 1,393$ & $\$ 1,281$ & $\$ 1,356$ & $102.8 \%$ \\
\hline 18 & $\$ 1,342$ & $\$ 1,230$ & $\$ 1,304$ & $102.9 \%$ \\
\hline 19 & $\$ 1,290$ & $\$ 1,178$ & $\$ 1,253$ & $103.0 \%$ \\
\hline 20 & $\$ 1,238$ & $\$ 1,127$ & $\$ 1,201$ & $103.1 \%$ \\
\hline
\end{tabular}

